\title{
Two New Species of the Mite Genus Stereotydeus Berlese, 1901 (Prostigmata: Penthalodidae) from Victoria Land, and a Key for Identification of Antarctic and Sub-Antarctic Species
}

\author{
Claudia Brunetti ${ }^{1, *}{ }^{(\mathbb{D}}$, Henk Siepel $^{2}\left(\mathbb{D}\right.$, Pietro Paolo Fanciulli ${ }^{1}$, Francesco Nardi ${ }^{1}\left(\mathbb{D}\right.$, Peter Convey $^{3}(\mathbb{D})$ \\ and Antonio Carapelli ${ }^{1, *(D)}$ \\ 1 Department of Life Sciences, University of Siena, Via A. Moro 2, 53100 Siena, Italy; \\ paolo.fanciulli@unisi.it (P.P.F.); francesco.nardi@unisi.it (F.N.) \\ 2 Animal Ecology and Physiology, Radboud Institute for Biological and Environmental Sciences (RIBES), \\ Radboud University, P.O. Box 9100, 6500 GL Nijmegen, The Netherlands; henk.siepel@ru.nl \\ 3 British Antarctic Survey, NERC, High Cross, Madingley Road, Cambridge CB3 0ET, UK; pcon@bas.ac.uk \\ * Correspondence: clabrunetti12@gmail.com (C.B.); antonio.carapelli@unisi.it (A.C.); \\ Tel.: +39-0577-234398 (C.B.); +39-0577-234410 (A.C.)
}

\section{check for}

updates

Citation: Brunetti, C.; Siepel, H.; Fanciulli, P.P.; Nardi, F.; Convey, P.; Carapelli, A. Two New Species of the Mite Genus Stereotydeus Berlese, 1901 (Prostigmata: Penthalodidae) from Victoria Land, and a Key for Identification of Antarctic and Sub-Antarctic Species. Taxonomy 2021, 1, 116-141. https://doi.org/10.3390/ taxonomy 1020010

Academic Editor: Peter Michalik

Received: 20 April 2021

Accepted: 14 May 2021

Published: 19 May 2021

Publisher's Note: MDPI stays neutral with regard to jurisdictional claims in published maps and institutional affiliations.

Copyright: (C) 2021 by the authors Licensee MDPI, Basel, Switzerland. This article is an open access article distributed under the terms and conditions of the Creative Commons Attribution (CC BY) license (https:// creativecommons.org/licenses/by/ $4.0 /)$.

\begin{abstract}
Two new mite species belonging to the genus Stereotydeus Berlese, 1901 were discovered from locations along the coast of Victoria Land, continental Antarctica. Previous records of this genus in the area under study only reported the presence of S. belli and S. mollis. Although those studies included no morphological analyses, it has since been assumed that only these species were present within the area. Specimens of S. ineffabilis sp. nov. and S. nunatakis sp. nov. were obtained, sometimes in sympatry, from four different localities in Central and South Victoria Land and are here described and illustrated using optical and scanning electron microscopy (SEM) techniques. Features useful for identification of the two new Stereotydeus species include the size of the specimens, the length of the apical segment of pedipalps, the presence/absence of division of the femora, the position of solenidia, the shape and disposition of the rhagidiform organs on the tarsi, the shape of the apical setae of the tarsi, the numbers of aggenital setae and the position of the anal opening. A key to 14 of the 15 currently described Antarctic and sub-Antarctic Stereotydeus species is provided.
\end{abstract}

Keywords: Antarctica; Victoria Land; Acari; terrestrial invertebrates; taxonomy; taxonomic key; Stereotydeus ineffabilis sp. nov.; Stereotydeus nunatakis sp. nov.

\section{Introduction}

Free-living mites are amongst the most abundant and widespread group of Antarctic arthropods [1,2], with the best-represented groups being Prostigmata, Oribatida and Mesostigmata. Within the continental and maritime Antarctic regions, 40 different species have been recorded considering only the two first orders, with 12 genera from six families for Prostigmata and eight genera from seven families for Oribatida [3]. Within the Prostigmata, one of the most represented families is Penthalodidae, which includes the cosmopolitan genus Stereotydeus Berlese, 1860 [4]. To date, a total of 13 Stereotydeus species have been recorded in Antarctica: six from continental Antarctica, one from maritime Antarctica, and seven from the sub-Antarctic (Table A1). Three members of the genus (S. belli (Trouessart, 1902), S. delicatus Strandtmann, 1967 and S. punctatus Strandtmann, 1967) are known from Northern Victoria Land and two (S. mollis Womersley and Strandtmann, 1963 and S. shoupi Strandtmann, 1967) from Southern Victoria Land and the immediate vicinity of the central Transantarctic Mountains (Table A1). Since the original morphological studies conducted on Antarctic Stereotydeus species (e.g., [2,5-7]), little research has been carried out on the genus in recent years, with studies investigating their physiology, ecology [8-10] and molecular diversity [11-13]. With the combination of great morphological and genetic variability emerging from these studies and the incomplete and 
fragmented information about their distribution in coastal regions of Victoria Land, we conducted a morphological taxonomy study of two newly discovered Stereotydeus species from the region. A more detailed population genetic study inclusive of several Stereotydeus species (Brunetti et al., unpublished data) will provide a wider picture of the distribution in Victoria Land of taxa of the genus. These are of interest both in terms of taxonomic knowledge of the genus and in underpinning the development of future conservation plans in the Antarctic.

\section{Materials and Methods}

\subsection{Samples Collection and Preparation}

Stereotydeus specimens were collected from four different locations along the Victoria Land coast (Table 1) during the 2017-2018 and 2018-2019 Antarctic summer expeditions of the Italian National Antarctic Research Program (PNRA: PNRA16_00234), immediately preserved in absolute ethanol and stored at room temperature. Between 11 and 32 specimens from each population (Table 1) were placed on a slide with few drops of lactic acid $(20 \%)$ at room temperature for three weeks, allowing the samples to clear. Individuals were then observed under a Leica DM RBE microscope. For preparing illustrations, a camera lucida attached to a Leica DM LB microscope was used. The specimens used were then transferred to slides in Hoyer's mounting medium for permanent preservation.

Table 1. Sampling location details including respective area codes and coordinates, the date of collection, the altitude of the sampling site and numbers of the specimens prepared for optical microscopy (n.) and scanning electron microscopy (SEM).

\begin{tabular}{|c|c|c|c|c|c|c|}
\hline Area & ID Area & Coordinates & Date & Altitude & n. & SEM \\
\hline Campo Icaro & CIC & $\begin{array}{c}74^{\circ} 42^{\prime} 45^{\prime \prime} \mathrm{S} \\
164^{\circ} 06^{\prime} 21^{\prime \prime} \mathrm{E}\end{array}$ & $\begin{array}{l}24 / 12 / 17 \\
28 / 01 / 19\end{array}$ & $70 \mathrm{~m}$ & $\begin{array}{c}9 \\
16\end{array}$ & $\begin{array}{l}4 \\
5\end{array}$ \\
\hline $\begin{array}{l}\text { Inexpressible } \\
\text { Island }\end{array}$ & INE & $\begin{array}{c}74^{\circ} 53^{\prime} 39^{\prime \prime} \mathrm{S} \\
163^{\circ} 43^{\prime} 44^{\prime \prime} \mathrm{E}\end{array}$ & $21 / 01 / 19$ & $30 \mathrm{~m}$ & 15 & 6 \\
\hline Prior Island & PRI & $\begin{array}{l}75^{\circ} 41^{\prime} 31^{\prime \prime} \mathrm{S} \\
162^{\circ} 52^{\prime} 34^{\prime \prime} \mathrm{E}\end{array}$ & $\begin{array}{l}11 / 01 / 18 \\
11 / 01 / 19\end{array}$ & $130 \mathrm{~m}$ & $\begin{array}{l}14 \\
18\end{array}$ & $\begin{array}{c}- \\
10\end{array}$ \\
\hline Starr Nunatak & SNU & $\begin{array}{c}75^{\circ} 53^{\prime} 57^{\prime \prime} \mathrm{S} \\
162^{\circ} 35^{\prime} 08^{\prime \prime} \mathrm{E}\end{array}$ & $\begin{array}{l}11 / 01 / 18 \\
11 / 01 / 19\end{array}$ & $60 \mathrm{~m}$ & $\begin{array}{l}7 \\
4\end{array}$ & $\begin{array}{l}5 \\
-\end{array}$ \\
\hline
\end{tabular}

Some individuals were also prepared for scanning electron microscope (SEM) observation (Table 1). To better clean the samples, an additional washing step with absolute ethanol was performed. Then, the ethanol was removed by evaporation in a Balzer CPD 010 reaching the $\mathrm{CO}_{2}$ critical point. Individuals were then placed on an aluminum stub and coated with gold-palladium in a Balzer MED 010, before observation using a Philips XL20 electron microscope.

\subsection{Morphological Characters under Study}

Characters used to identify the genus Stereotydeus include the presence of a trilobed epirostrum with epivertex at the base of the middle lobe and genitalia in a nearly circular camerostome covered by two valves separated from the body by a distinct suture [7]. Characters used to separate different species include the division in two segments of the femora, the degree of development of the epirostrum and dorsal sculpturing. In addition, the following features were useful in distinguishing the species described here from those already known: body length, the position of solenidia, length of the apical (4th) segment of pedipalps and length of the movable digits of the chelicerae, presence of rhagidial organs on the tibiae, the symmetry or asymmetry of the rhagidiform organs on the tarsi and the shape of the apical setae on top of the tarsi, numbers of the aggenital setae and the position (distal/ventral) of the anal opening on the hysterosoma. 


\section{Results}

\subsection{Systematics}

Phylum Arthropoda Latreille 1829

Super-order Acariformes Zachvatkin, 1952

Order Trombidiformes Reuter 1909

Sub-order Prostigmata Kramer, 1877

Superfamily Eupodoidea Koch 1842

Family Penthalodidae Thor 1933

Genus Stereotydeus Berlese, 1901

Stereotydeus ineffabilis sp. nov. Brunetti and Siepel.

Type Locality: Inexpressible Island $\left(74^{\circ} 53^{\prime} 39^{\prime \prime} \mathrm{S} 163^{\circ} 43^{\prime} 44^{\prime \prime} \mathrm{E}\right)$, Central Victoria Land, continental Antarctica.

Holotype: slide STI1, male, 21.i.2019. Collected by A. Carapelli. Deposited in the Collection of the Department of Life Sciences of the University of Siena.

Paratypes: STI2, male, Prior Island $\left(75^{\circ} 41^{\prime} 31^{\prime \prime} \mathrm{S} 162^{\circ} 52^{\prime} 34^{\prime \prime} \mathrm{E}\right)$, South Victoria Land, continental Antarctica, 11.i.2019; STI3_I2, male, Inexpressible Island, 21.i.2019; STI4, male, Inexpressible Island, 21.i.2019; STI5, male, Prior Island, 11.i.2019. Deposited in the Collection of the Department of Life Sciences of the University of Siena.

Material Examined for the Description: Prior Island, $2+6$ slides (the former number indicates slides with multiple individuals, while the latter number indicates slides with a single individual) $\left(10+1\right.$ \%, $10+5{\sigma^{7}}^{7}, 4+0$ nymphs); Inexpressible Island, $1+6$ slides $\left(6+3\right.$ +, $\left.4+20^{\prime}\right)$; Campo Icaro $\left(74^{\circ} 42^{\prime} 45^{\prime \prime} \mathrm{S} 164^{\circ} 06^{\prime} 21^{\prime \prime} \mathrm{E}\right)$, Central Victoria Land, continental Antarctica, $1+2$ slides $\left(2+1\right.$ i, $3+0 \circ^{\prime \prime}, 4+1$ nymphs); Starr Nunatak $\left(75^{\circ} 53^{\prime} 57^{\prime \prime} \mathrm{S}\right.$ $162^{\circ} 35^{\prime} 08^{\prime \prime}$ E), South Victoria Land, continental Antarctica, 3 slides $\left(1+, 20^{\top}\right)$. All specimens were collected by A. Carapelli and are deposited in the Collection of the Department of Life Sciences of the University of Siena.

Etymology: From Latin, "ineffabilis" meaning inexpressible, ineffable because of its fragile nature.

Description: Soft-bodied mite with a barely visible sculptured pattern on the prodorsum and sclerotization almost absent. The body length of the Holotype is $408.44 \mu \mathrm{m}$; the average length of adult specimens studied is $414 \mu \mathrm{m}$, with values ranging from 369 to $460 \mu \mathrm{m}( \pm 25 \mu \mathrm{m})$. The size is smaller than S. mollis [2,5]. The shape of the body is similar to the other species of the genus. The propodosoma is divided from the hysterosoma by a distinct sejugal furrow. The morphological features are illustrated in Figures 1-5.

Dorsal side: The epirostrum is trilobed but with the two lateral lobes weakly developed and with a slightly striated epivertex with two ciliated setae at the base of the middle lobe (Figures $1 \mathrm{a}$ and $5 \mathrm{c}$ ). The eyes are convex and lightly striated. Three pairs of slit pores are present on each side of the dorsum (Figures $1 \mathrm{a}$ and $5 \mathrm{a}$ ); as for other species of the genus, the hysterosoma carries 8 pairs of plumose setae (Figures 1a and 5a).

Ventral side: As in other species of the genus, the genitalia are situated in a circular camerostome protected by two valves which, under the optical microscope, laterally are hardly separated from the body wall (as in S. mollis) (Figures $1 \mathrm{~b}$ and $5 \mathrm{~b}$ ). Seven pairs of internal genital setae are present (Figures $1 b$ and $5 b$ ). Each genital valve has 6 setae, of which the fourth is more lateral. The aggenital setae are present in 5 pairs, but often the specimens observed showed asymmetry in the number with a total of 9 setae (Figures $1 \mathrm{~b}$ and $5 \mathrm{~b}$ ). The anal opening in ventral and distal position is smaller than the genital pore, and it is covered by two valves and surrounded by 3 pairs of plumose setae.

Gnathosoma: Rostrum triangular with 2 pairs of nude apical setae. Chelicerae plump, finely pubescent; movable digit about the same length as the fixed digit; two setae at the base of the movable digit and shorter than the digit itself (Figure 1c). Pedipalps finely pubescent with the terminal segment slightly slender and same length as the sub-terminal segment (Figure 1d) with basal dorso-lateral rhagidiform organ and 7 apical setae. 


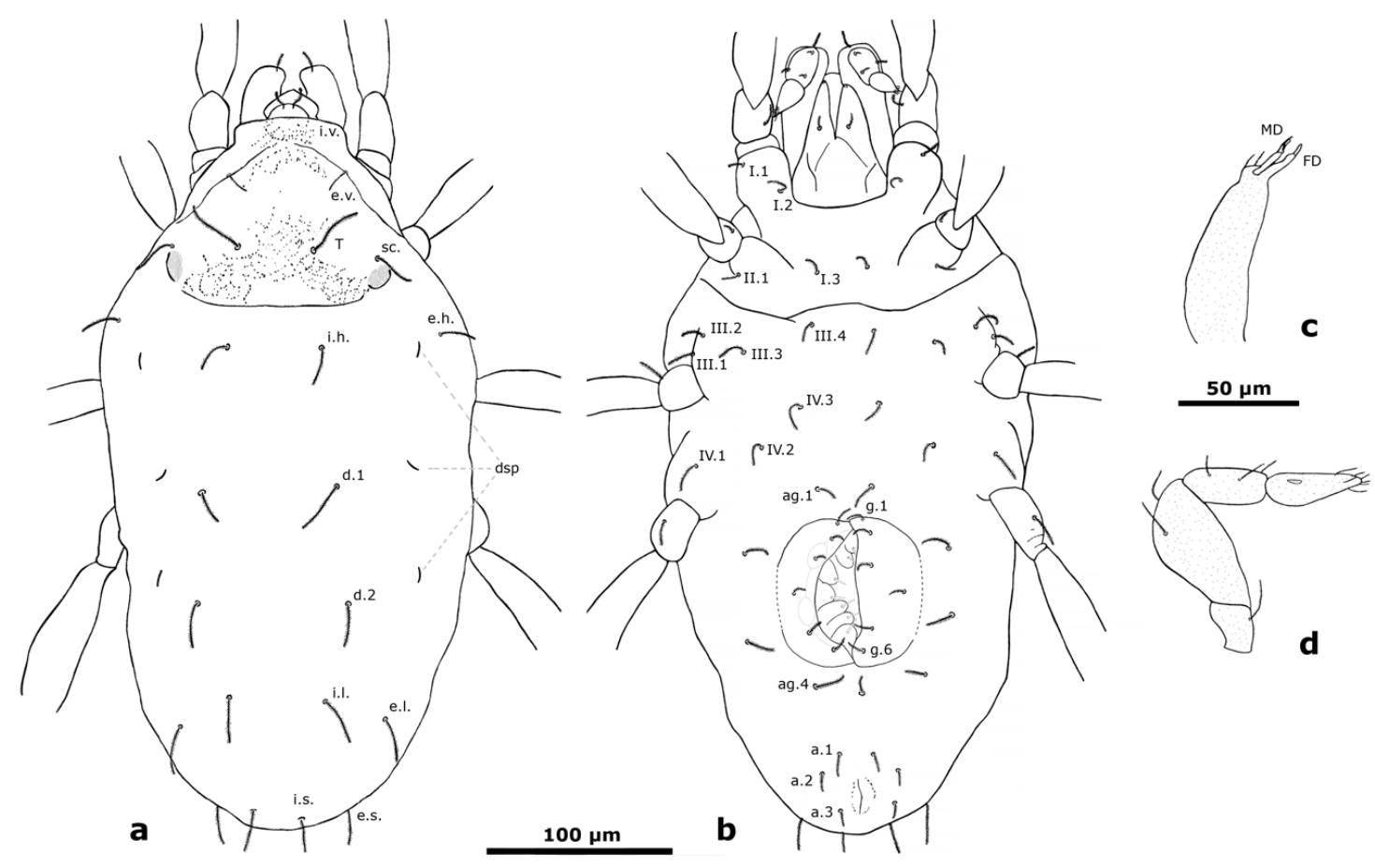

Figure 1. Stereotydeus ineffabilis sp. nov. (a) Dorsal view; (b) ventral view; (c) chelicera and (d) lateral view of the pedipalp. Dorso-lateral slit pores (dsp); movable digit (MD) and fixed digit (FD) of chelicerae. Names of dorsal setae: internal vertical (i.v.), external vertical (e.v.), trichobothrium (T), scapular (sc.), external humeral (e.h.), internal humeral (i.h.), 1st and 2nd dorsals (d.1, d.2), internal lumbar (i.l.), external lumbar (e.1.), internal sacral (i.s.) and external sacral (e.s.). Names of ventral setae: coxal setae (I-IV), aggenital setae (ag.), genital setae (g.) and anal setae (a.).

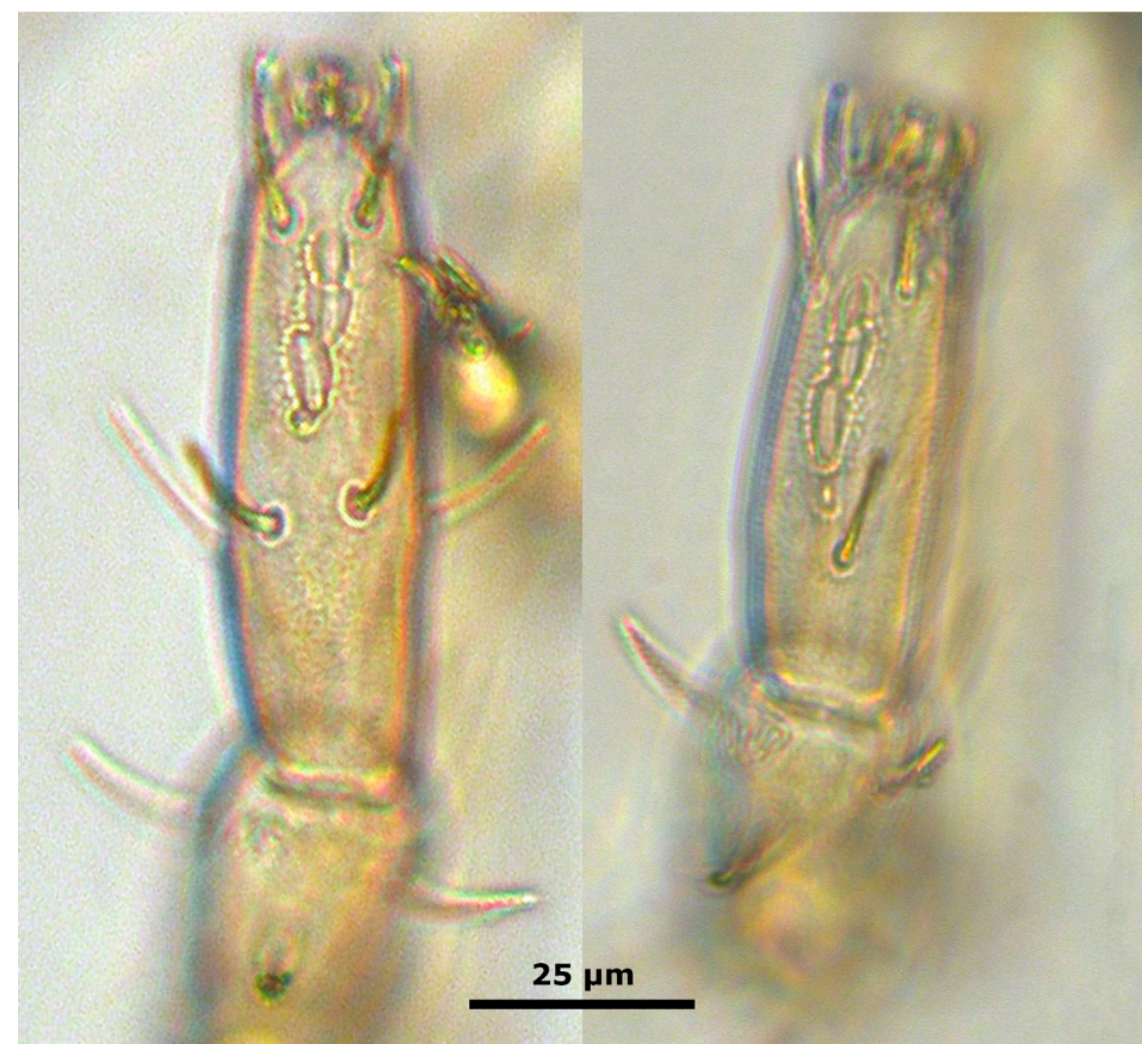

Figure 2. S. ineffabilis sp. nov. Asymmetry of the rhagidial organs on tarsi I (left) and II (right) subtended by small nude round setae in the specimens from Inexpressible Island. Apical rhagidial organs on tibiae I and II also visible. 


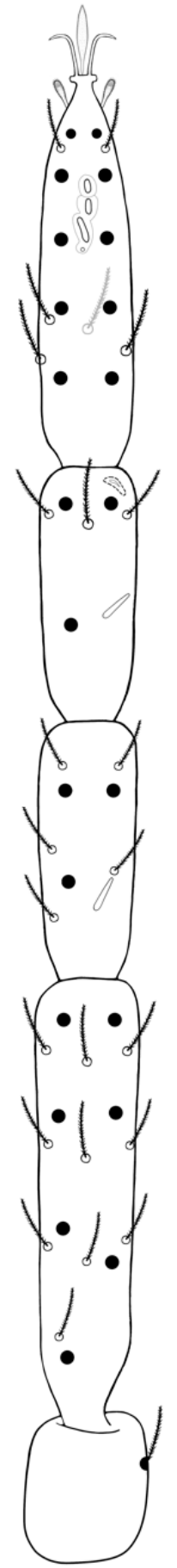

I

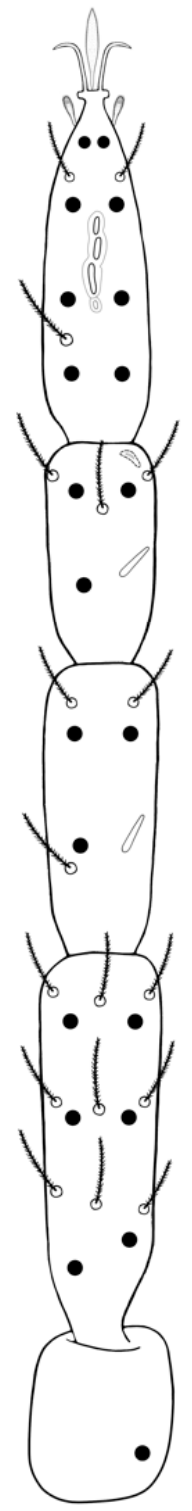

II

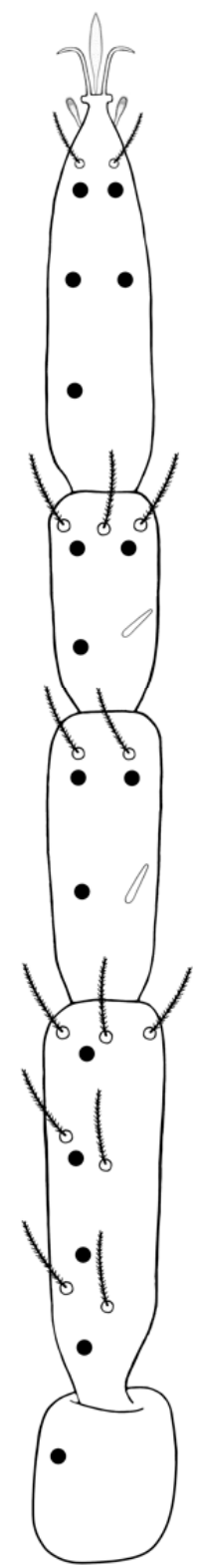

III

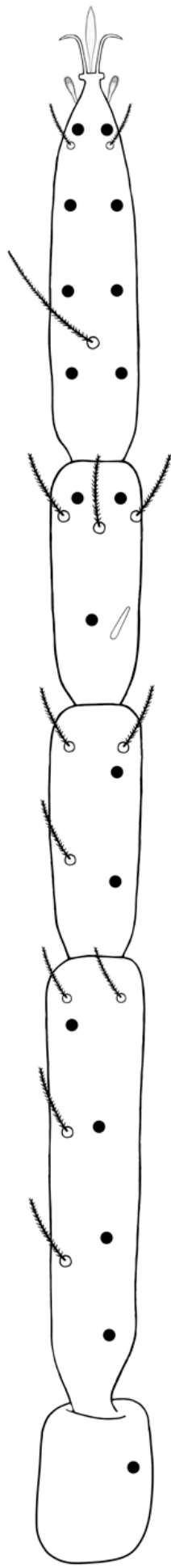

IV

$100 \mu \mathrm{m}$

Figure 3. S. ineffabilis sp. nov. Chaetotaxy of legs of Inexpressible Island specimens; black dots represent the setae on the ventral side; light grey indicates setae that are sometimes missing; rhagidial organs visible on tarsi I and II and subtended by small nude round setae; outlines after the drawings of Pittard [2] arranged with proportions and details of $S$. ineffabilis individuals. 


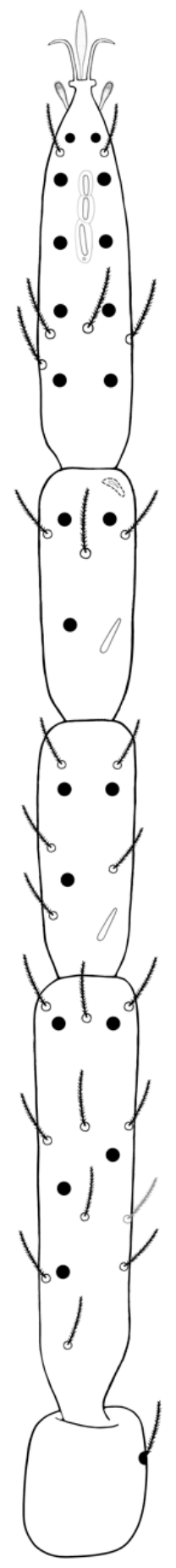

I

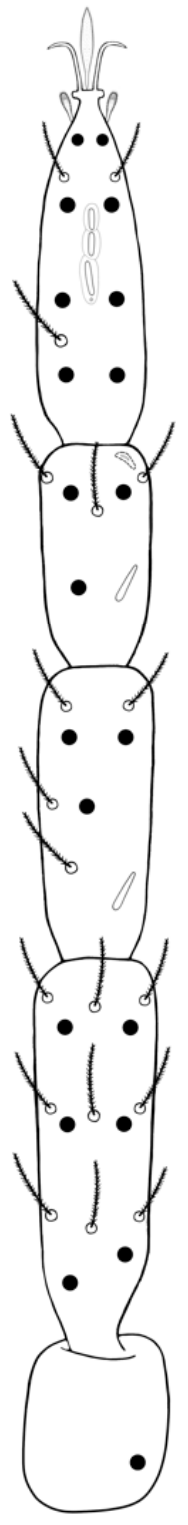

II

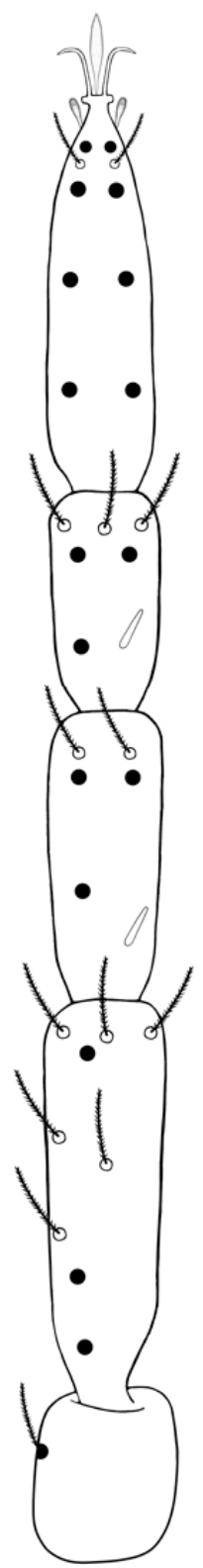

III

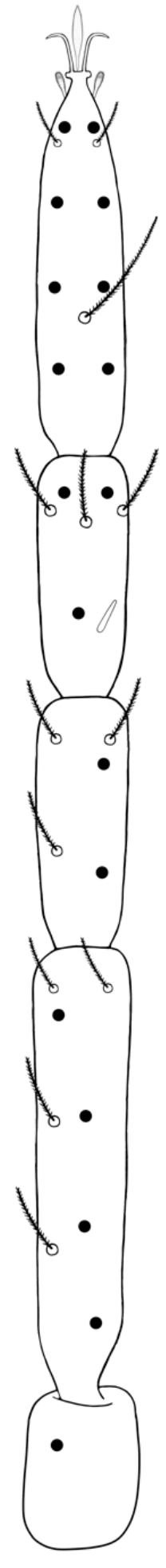

IV

Figure 4. S. ineffabilis sp. nov. Chaetotaxy of legs of Prior Island specimens; black dots represent the setae on the ventral side; light grey indicates setae that are sometimes missing; rhagidial organs visible on tarsi I and II and subtended by small nude round setae; outlines after the drawings of Pittard [2] arranged with proportions and details of S. ineffabilis. 


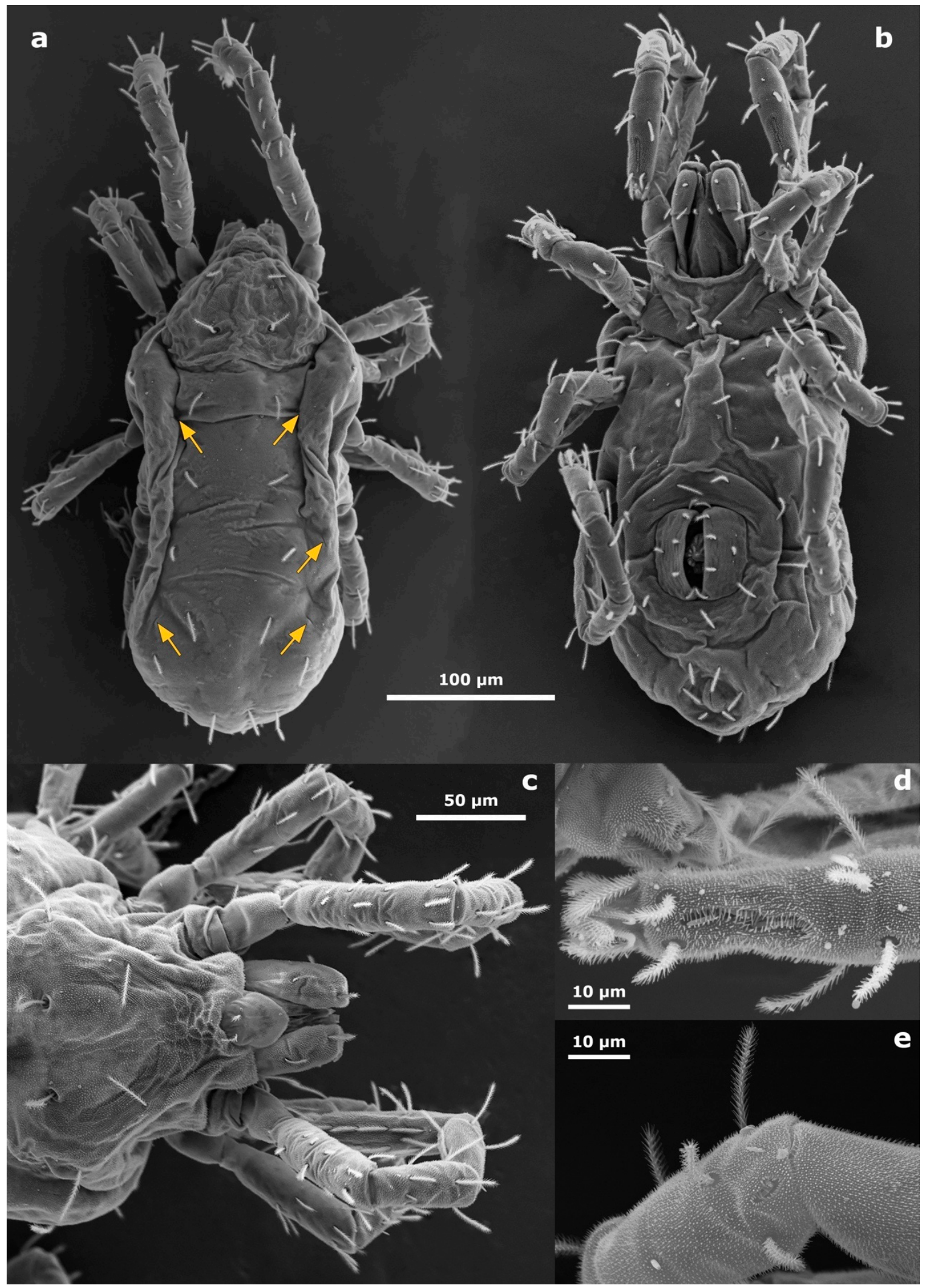

Figure 5. S. ineffabilis sp. nov. Scanning electron microscopy. (a) dorsal view, slit pores visible, indicated by orange arrows; (b) ventral view with internal genital setae and asymmetry in the aggenital setae visible; (c) detail of the propodosoma, epirostrum visible; (d) asymmetry in the rhagidial organs on tarsus I of a specimen from Inexpressible Island and (e) tibia I, rhagidial organ and solenidium visible. 
Legs: The legs are slender and shorter than the body: the second pair is shorter than the other pairs but almost comparable in length with the third while the first pair is slightly shorter than the fourth (Figures 3 and 4). Coxal setal formula: 3, 1, 4, 3. All femora are undivided. Solenidia: basal and dorsal on genua I, II and III; at 2/3 (mid-basal) of the tibia's length in all legs of the specimens. Tibiae I and II with a small apical rhagidial organ, as in S. mollis (Figure 5b,e). Tarsi I and II with three different rhagidiform organs: the two apicals are smaller than the basal one, longer and obliquely placed in a confluent (tarsi I) or continuous (tarsi II) field (Figures 2 and 5d). In the samples from Prior Island, the three rhagidiform organs on tarsi I and II are often in line with the basal one, only slightly oblique in confluent fields (Figure 5b). A small nude round seta is present at the base of the latter rhagidial organ on tarsi I and II (Figures 2-4). Chaetotaxy of the legs very variable: trochanters with 1 seta, femora I, II, III and IV with 17 in INE and 16 (or 15; one is weaker and less developed, sometimes missing) in PRI, 15, 11 (INE) and 9 (PRI) and 8 setae, respectively; genua I, II, III and IV with 8, 6 (INE) or 7 (PRI), 5 and 5 setae, respectively; all tibiae with 6 setae each; tarsi I, II, III and IV with 18 (sometimes 17 in INE), 13, 9 (INE) or 12 (PRI) and 13, respectively; leaf-shaped, brush-like setae between the claws on top of the empodia (Table 2; Figures 3 and 4).

Table 2. Leg chaetotaxy of S. ineffabilis specimens from Inexpressible Island and Prior Island. Dorsal and ventral refer to surfaces of the leg segments; solenidia are excluded from the count while trichobothria are included (see Figures 3 and 4 for the details and position of leg chaetotaxy). c. coxa, tr. trochanter, $f$. femur, g. genu, ti. tibia and $t a$. tarsus.

\begin{tabular}{|c|c|c|c|c|c|c|c|c|}
\hline Area & & Leg & $c$. & $t r$ & $f$ & $g$. & $t i$. & $t a$. \\
\hline \multirow{8}{*}{ Inexpressible Island } & \multirow{4}{*}{ Dorsal } & I & 0 & 0 & $10-11$ & 5 & 3 & 8 \\
\hline & & II & 0 & 0 & 9 & 4 & 3 & 5 \\
\hline & & III & 0 & 0 & 6 & 2 & 3 & 4 \\
\hline & & IV & 0 & 0 & 4 & 3 & 3 & 5 \\
\hline & \multirow{4}{*}{ Ventral } & I & 3 & 1 & 5 & 3 & 3 & 10 \\
\hline & & II & 1 & 1 & 6 & 3 & 3 & 8 \\
\hline & & III & 4 & 1 & 3 & 3 & 3 & 8 \\
\hline & & IV & 3 & 1 & 4 & 2 & 3 & 8 \\
\hline \multirow{8}{*}{ Prior Island } & \multirow{4}{*}{ Dorsal } & I & 0 & 0 & 10 & 5 & 3 & $7-8$ \\
\hline & & II & 0 & 0 & 9 & 3 & 3 & 5 \\
\hline & & III & 0 & 0 & 7 & 2 & 3 & 4 \\
\hline & & IV & 0 & 0 & 4 & 3 & 3 & 5 \\
\hline & \multirow{4}{*}{ Ventral } & I & 3 & 1 & 7 & 3 & 3 & 10 \\
\hline & & II & 1 & 1 & 6 & 3 & 3 & 8 \\
\hline & & III & 4 & 1 & 4 & 3 & 3 & 5 \\
\hline & & IV & 3 & 1 & 4 & 2 & 3 & 8 \\
\hline
\end{tabular}

Remarks: Comparing S. ineffabilis adults with S. mollis as described in $[2,5,7,14]$, the characters that help to positively identify and distinguish $S$. ineffabilis were: (i) the smaller size of the adults; (ii) the number of the aggenital setae (10 or 9 in S. ineffabilis, 8 in S. mollis); (iii) asymmetry in the tarsal rhagidial organs in S. ineffabilis specimens; (iv) the terminal (4th) segment of the pedipalps being as long as the sub-terminal (3rd) and bearing 7 setae in S. ineffabilis (while in S. mollis the 4th segment has a cluster of 8 setae and is longer than the 3rd segment); (v) the equal length of the movable and fixed digits of the chelicerae in $S$. ineffabilis (while in S. mollis the 4th segment is longer than the 3rd) and (vi) the position of the solenidia on the tibiae and the genua. Two specimens (one male from Campo Icaro and one from Inexpressible Island) showed a wrinkle (like a hint of division) at the apical quarter of the femora (in I and II, the wrinkle is barely visible while in III and IV it is clearer) and ventral but almost terminal position of the anal opening. Another specimen from INE prepared for SEM showed wrinkles at the terminal part of the femora. The indication of femora divisions observed under the optical microscope technique may be due to the occurrence of the folding of the cuticle as shown with the SEM technique. 
Stereotydeus nunatakis sp. nov. Brunetti

Type Locality: Starr Nunatak ( $75^{\circ} 53^{\prime} 57^{\prime \prime} \mathrm{S} 162^{\circ} 35^{\prime} 08^{\prime \prime}$ E), South Victoria Land, continental Antarctica.

Holotype: slide STN1, male, 11.i.2019. Collected by A. Carapelli. Deposited in the Collection of the Department of Life Sciences at the University of Siena.

Paratypes: STN2, male, Starr Nunatak, 11.i.2019; STN3_P6, female, Prior Island $\left(75^{\circ} 41^{\prime} 31^{\prime \prime} \mathrm{S} 162^{\circ} 52^{\prime} 34^{\prime \prime}\right.$ E), South Victoria Land, continental Antarctica, 11.i.2019; STN4_S6, female, Starr Nunatak, 11.i.2018. Deposited in the Collection of the Department of Life Sciences at the University of Siena.

Material Examined for the Description: Starr Nunatak, $1+6$ slides $\left(2+2 q, 0+20^{7}\right.$, $0+2$ nymphs) and Prior Island, 2 slides with single individuals (2 +). All specimens collected by A. Carapelli and deposited in the Collection of the Department of Life Sciences at the University of Siena.

Etymology: named after the ice-free ridge at the holotype locality, Starr Nunatak, continental Antarctica.

Description: Soft-bodied mite well sclerotized with a clearly visible sculptured pattern on the dorsum. The body length of the holotype is $566.89 \mu \mathrm{m}$; the average length of the adult specimens studied is $563 \mu \mathrm{m}$, with values ranging from 537 to $582 \mu \mathrm{m}( \pm 13.57)$. The adults of the species are comparable in size with S. belli [5]. The shape of the body is similar to the other species of the genus and the furrow dividing the propodosoma from the hysterosoma is evident both ventrally and dorsally. The morphological features are illustrated in Figures 6-8.
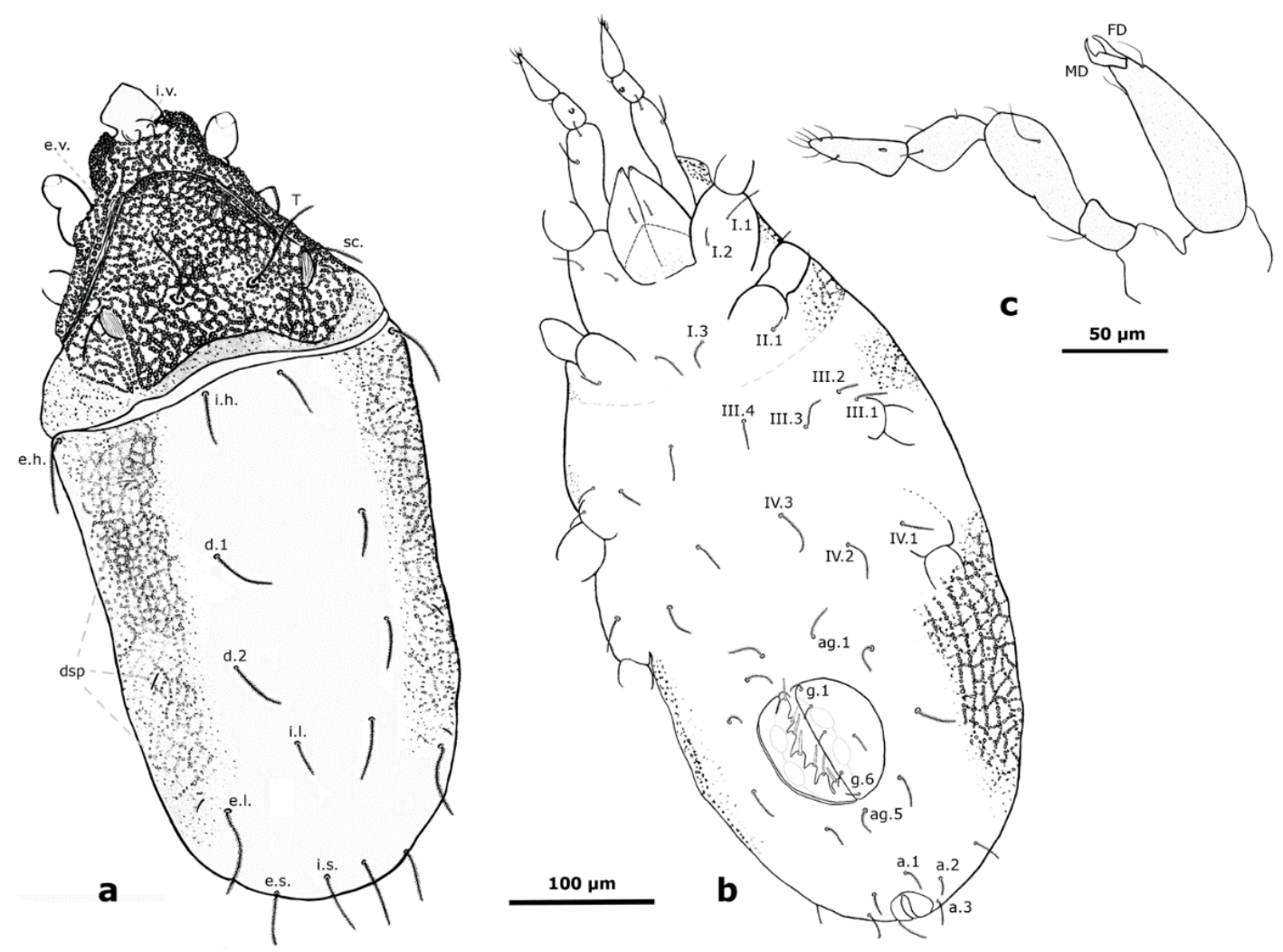

Figure 6. Stereotydeus nunatakis sp. nov. (a) Dorsal view; (b) ventral view and (c) lateral view of chelicera and pedipalp. Dorso-lateral slit pores (dsp); movable digit (MD) and fixed digit (FD) of chelicerae. Names of dorsal setae: internal vertical (i.v.), external vertical (e.v.), trichobothrium (T), scapular (sc.), external humeral (e.h.), internal humeral (i.h.), 1st and 2nd dorsals (d.1, d.2), internal lumbar (i.l.), external lumbar (e.1.), internal sacral (i.s.) and external sacral (e.s.). Names of ventral setae: coxal setae (I-IV), aggenital setae (ag.), genital setae (g.) and anal setae (a.). 


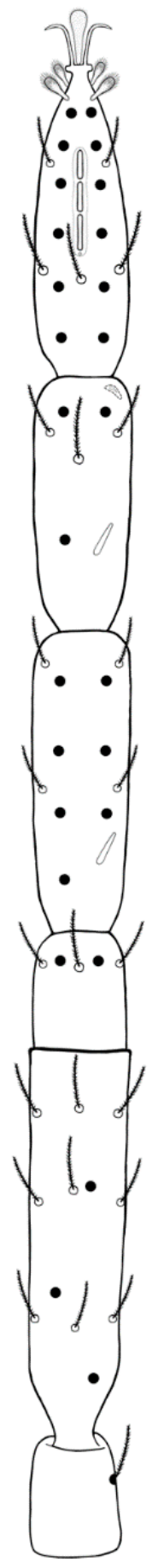

I

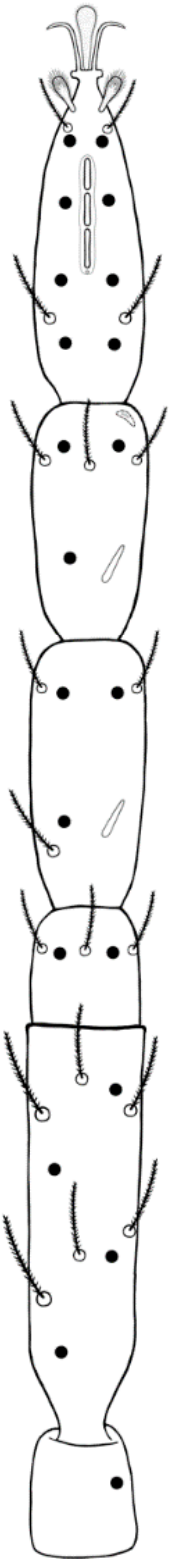

II

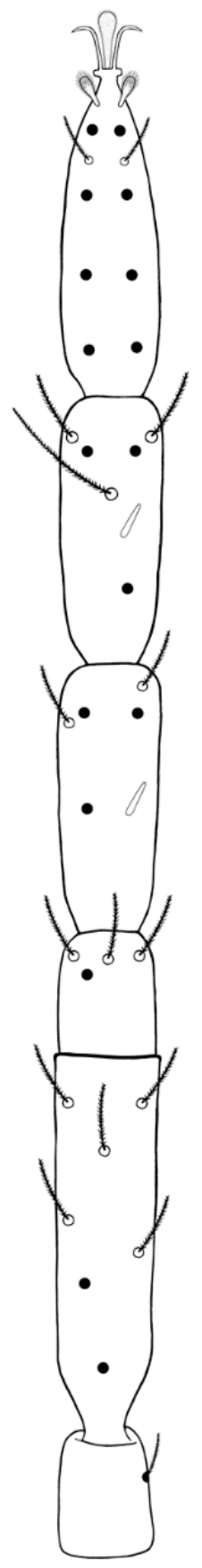

III

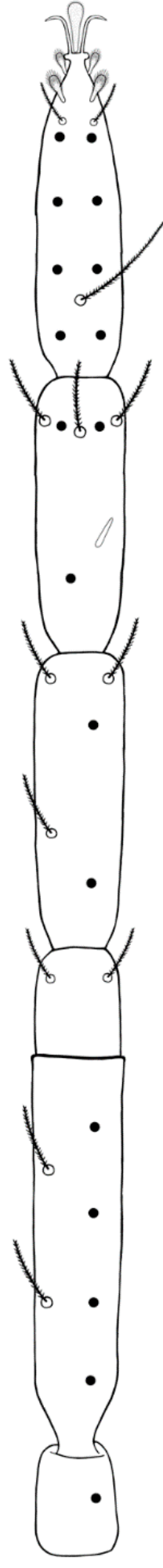

IV

Figure 7. S. nunatakis sp. nov. Leg chaetotaxy; black dots represent the setae on the ventral side; outlines after the drawings of Pittard [2] and arranged with proportions and details of S. nunatakis individuals. 


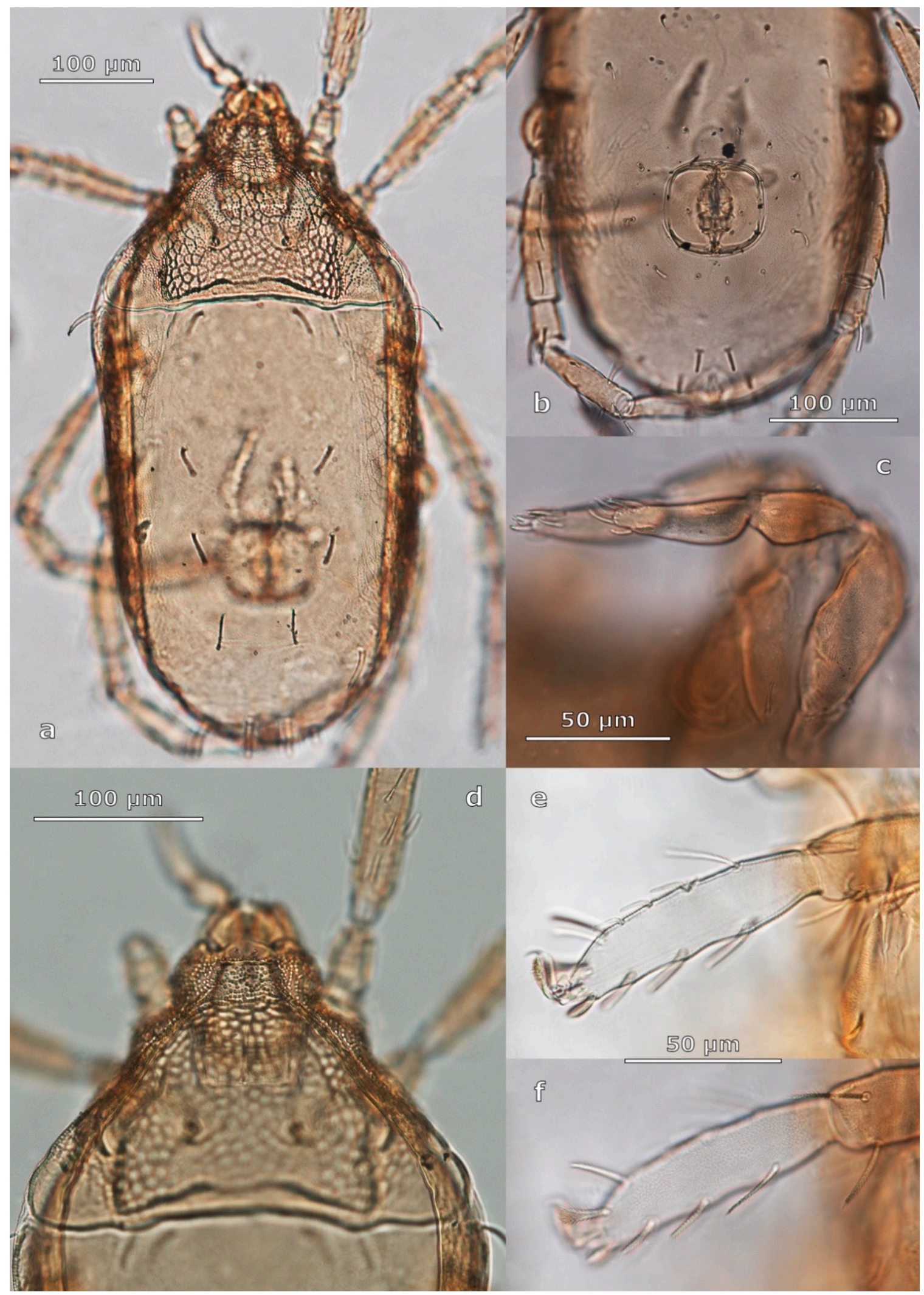

Figure 8. S. nunatakis sp. nov. (a) dorsal view; (b) ventral view with evident circular camerostome and visible asymmetry of the aggenital setae; (c) detail of the pedipalps; (d) detail of the propodosoma; (e) lateral view of the rhagidial organs on tarsus II and (f) clavate setae on top of tarsus II. 
Dorsal side: The epirostrum is strongly trilobed and lightly striated and the epivertex is almost smooth with two ciliated setae at the base of the middle lobe (Figures 6a and 8d). Propodosomal area is strongly sclerotized, more than the rest of the dorsum showing an evident reticulated pattern that lightly fades in the proximity of the sejugal furrow (Figures $6 \mathrm{a}$ and $8 \mathrm{~d}$ ). The eyes are convex and striated. Three pairs of slit pores are present on each side of the dorsum (Figure 6a): the first pair is horizontal (parallel to the sejugal furrow), and the two other pairs are oblique (Figure 6b); as for other species of the genus, the hysterosoma carries 8 pairs of plumose setae (as shown in the Figures 6a and 8a) almost all of the same length.

Ventral side: As in the other species of the genus, the genitalia are situated in a circular camerostome protected by two valves which laterally are well distinct from the body wall (as in S. belli). Seven pairs of internal genital setae (Figure 6a). Each genital valve holds 6 setae, of which the fourth is more lateral. The aggenital setae are present in 5 pairs, but specimens were also observed with asymmetry in the number $(4 / 5$ and 5/6) (Figures $6 \mathrm{~b}$ and $8 \mathrm{~b}$ ). The anal opening in ventral and distal position is smaller than the genital pore, and it is covered by two valves and surrounded by 3 pairs of plumose setae.

Gnathosoma: Rostrum triangular with 2 pairs of apical nude setae. Chelicerae are plump and finely pubescent, and the movable digit is longer than the fixed digit (Figure 6c). Two nude setae, one as long as the movable digit at the base of the fixed digit while the second is about half of the length of the movable digit, and it is positioned lower than the latter. Pedipalps finely pubescent with the terminal segment same length as the sub-terminal segment with 7 apical setae and basal dorso-lateral rhagidiform organ (Figures 6c and 8c).

Legs: The legs are slender and shorter than the body: the second pair is shorter, and the fourth pair which is longer than the others, while the first and third pairs are almost similar in length (Figure 7). Coxal setal formula: 3, 1, 4, 3. Trochanters all bearing 1 seta. All femora are divided. Solenidia: mid-basal (2/3) on tibiae I, II and IV and genua I and II, medial on tibia and genu III (but sometimes also mid-basal). Small apical rhagidial organ is present also on tibiae I and II. Tarsi I and II with three symmetrical rhagidiform organs similar in length laying in a common field (Figure 8e); a small nude round seta is present at the base of the proximal rhagidial organ on both tarsi I and II. Chaetotaxy of the legs: femora: 12/5, 10/5, 7/4,6/2; genua: 11,6, 5, 5; all tibiae with 6 setae each; tarsi: 21, 14, 12, 15; leg setae plumose except for 1-2 pairs at the tips of all tarsi clavate and brush-like (Figure 8f); bulb-shaped, brush-like setae between the claws on top of the empodia (Table 3; Figure 7).

Table 3. Chaetotaxy of S. nunatakis legs. Dorsal and ventral refer to surfaces of the leg segments; chaetotaxy in the femur shown as basal/apical segment; solenidia are excluded from the count, whereas trichobothria are included (see Figure 7 for the details and position leg chaetotaxy). c. coxa, tr. trochanter, $f$. femur, $g$. genu, $t i$. tibia and $t a$. tarsus.

\begin{tabular}{|c|c|c|c|c|c|c|c|}
\hline & Leg & $c$. & $t r$. & $f$. & $g$. & $t i$. & $t a$. \\
\hline \multirow{4}{*}{ Dorsal } & I & 0 & 0 & $9 / 3$ & 4 & 3 & 9 \\
\hline & II & 0 & 0 & $6 / 3$ & 3 & 3 & 6 \\
\hline & III & 0 & 0 & $5 / 3$ & 2 & 3 & 4 \\
\hline & IV & 0 & 0 & $2 / 2$ & 3 & 3 & 7 \\
\hline \multirow{4}{*}{ Ventral } & I & 3 & 1 & $3 / 2$ & 7 & 3 & 12 \\
\hline & II & 1 & 1 & $4 / 2$ & 3 & 3 & 8 \\
\hline & III & 4 & 1 & $2 / 1$ & 3 & 3 & 8 \\
\hline & IV & 3 & 1 & $4 /-$ & 2 & 3 & 8 \\
\hline
\end{tabular}

Remarks: Comparing S. nunatakis adults with other Stereotydeus species, the species appears more closely related to S. punctatus as described in Strandtmann [7] and to S. belli as described in Womersley and Strandtmann, and Strandtmann [5,7], sharing division of all the femora at the apical quarter, the prominent dorsal sculpturing and the apical (4th) 
segment of the pedipalps being as long as the 3rd, while, for the size of the adults, the number and position of the rhagidial organs on tarsi I and II of S. nunatakis are comparable only with $S$. belli as described in Womersley and Strandtmann [5]. Conversely, the characters that help to positively identify and distinguish adults of $S$. nunatakis from both $S$. belli and S. punctatus were: (i) the number of aggenital setae (10 with possible asymmetry of 9 or 11 in S. nunatakis, while 8 in S. punctatus and 22 in S. belli); (ii) the terminal (almost apical) position of the anal opening in S. nunatakis (while sub-terminal in S. belli and dorsal in $S$. punctatus); (iii) the position of the solenidia is mid-basal on tibiae and genua I, II and tibia IV and medially on tibia and genu III in S. nunatakis (while in S. punctatus all are basal on tibiae I-IV and genua I-III, and in S. belli are apical on tibiae and genua I, II and tibia III and medial on genua III and tibia IV); (iv) the bulb-shaped and brush-like setae terminally on the tarsi in S. nunatakis (while in S. punctatus and S. belli these setae are slender and plumose, not different from all the others present on the legs); (v) the 4th segment of the pedipalps bearing 7 plumose setae in S. nunatakis (while 8 in S. belli) and, finally, (vi) the chaetotaxy of the legs.

\subsection{Key to the Antarctic and Sub-Antarctic Stereotydeus Species}

This key includes 14 of the 15 Stereotydeus species described to date from continental and maritime Antarctica and the sub-Antarctic islands. Stereotydeus intermedius Trouessart, 1907 is excluded from the key due to the lack of information and data about this species [7,15-17] (see Tables A1-A7 in Appendix A). Additional information about morphological characteristics useful for identification is provided in Appendix A (Tables A1-A7). This key was constructed based on the original morphological descriptions of the known species. Besides S. ineffabilis and S. nunatakis, specimens of S. belli, S. punctatus and S. delicatus from Victoria Land were also available for morphological examination. A separate molecular phylogenetic analysis of these five species is currently being carried out (Brunetti et al., unpublished data).

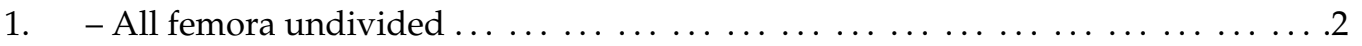

- All femora divided at apical $\frac{1}{4} \ldots \ldots \ldots \ldots \ldots \ldots \ldots \ldots \ldots \ldots \ldots \ldots \ldots \ldots$

2. - Lateral lobes of the epirostrum weakly developed, dorsal sculpturing weak or absent

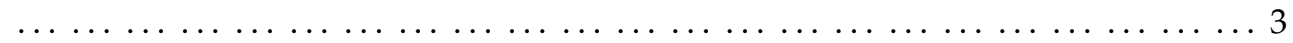

- Lateral lobes of the epirostrum well developed, dorsal sculpturing prominent pitted

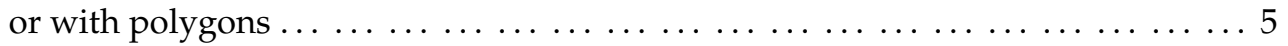

3. - Genital setae 7 (pairs), 4th (apical) segment of pedipalps shorter than 3rd, middle lobe of the epirostrum not developed, eyes indistinct, coxae well distinct; solenidia apical on tibiae I-II and genu I, subapical on genu II, 2 trichobothria (tarsus and tibia IV) ............................... shoupi Strandtmann, 1967

- Genital setae 6 (pairs), 4th segment of pedipalps longer or equal to 3rd, middle lobe of the epirostrum obtusely pointed and evident, eyes evident, coxae indistinct; solenidia medial or mid-basal on all tibiae and genua, 1 trichobothria on tarsus IV . . . . . 4

4. - Average body length $500 \mu \mathrm{m}$, 4th segment of pedipalps longer than 3rd, 8 apical palpal setae, dorso-lateral slit pores absent, aggenital setae 4 pairs, mid-dorsal solenidia on tibiae I-IV and genua I-III, symmetric rhagidial organs in confluent fields on tarsi I-II . . . . . . . . . . . . . . . . S. mollis Womersley and Strandtmann, 1963

- Average body length $400 \mu \mathrm{m}$, 4th segment of pedipalps equal to 3rd, 7 apical palpal setae, 3 pairs of dorso-lateral slit pores on hyesterosoma, aggenital setae 5 pairs (frequently asymmetric), mid-basal solenidia on tibiae I-IV and mid-basal or basal on genua I-III, asymmetric rhagidial organs in 2 (sometimes 3 ) separated fields on tarsi I-II . . . . . . . . . . . . . . . . . . . . . . . . . . . . S. ineffabilis sp. nov.

5. - Average body length $525 \sigma^{7}-540$ \% $\mu \mathrm{m}$, middle lobe of the epirostrum obtusely pointed, 4th segment of pedipalps longer or equal to 3rd, shallow sejugal furrow, no longitudinal grooves, coxae well distinct, trichobothrium on tarsus IV, 3 rhagidial organs in common fields on tarsi I-II ... . . . . . . S. longipes Strandtmann, 1970 
- Average body length $500 \mu \mathrm{m}$, middle lobe of the epirostrum round (half-circle), 4th segment of pedipalps shorter than 3rd, evident sejugal furrow connected with 2 prominent longitudinal grooves forming a $\mathrm{H}$, coxae indistinct, no trichobothria, 3 rhagidial organs in separated fields on tarsi I-II (2 parallels, 1 oblique) ... S. pulcher Strandtmann, 1964

6. - Anal opening dorsal ... . . . . . . . . . . . . . . . punctatus Strandtmann, 1967

- Anal opening ventral and/or sub-terminal $\ldots \ldots \ldots \ldots \ldots \ldots \ldots \ldots \ldots$

7. - Aggenital setae 4 or 5 pairs, sejugal furrow shallow or visible only dorsal $\ldots \ldots \ldots 8$

- Aggenital setae 10 pairs or more, sejugal furrow evident . . . . . . . . . . 11

8. - Aggenital setae 4 pairs, legs without trichobothria, coxae well distinct . . . . . . .9

- Aggenital setae 5 pairs or asymmetric $(4 / 5,5 / 6)$, legs with 2 trichobothria in total,

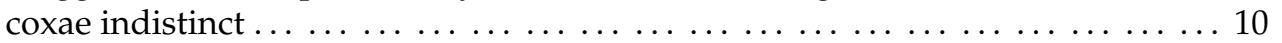

9. - Average body length $450 \mu \mathrm{m}$, 4th segment of pedipalps longer than 3rd, lateral lobes of epirostrum weakly developed, anal opening sub-terminal in apical position, only propodosoma faintly reticulated ............ S. delicatus Strandtmann, 1967

- Average body length $400 \mu \mathrm{m}$, 4th segment of pedipalps equal to 3rd, lateral lobes of epirostrum well developed, anal opening sub-terminal but not apical, entire dorsum delicately reticulated . . . . . . . . . . . . . . . S. meyeri Strandtmann, 1967

10. - Average body length $435 \mu \mathrm{m}$, 4th segment of pedipalps longer than 3rd, lateral lobes of epirostrum large, triangular and tubercolate, tarsi I-II with 3 rhagidial organs: I in separate fields, II with two apicals in common field and basal one in separated field $\ldots \ldots \ldots \ldots \ldots \ldots \ldots \ldots \ldots \ldots$. . . . . . . . . . . . . . . . . . . . . - Average body length $560 \mu \mathrm{m}$, 4th segment of pedipalps equal to 3rd, lateral lobes of epirostrum narrow and well developed, aggenital setae 5 pairs (sometimes $4 / 5$ or 5/6), tarsi I-II with 3 rhagidial organs in line in common field ... ... S. nunatakis sp. nov.

11. - Average body length $560 \mu \mathrm{m}, 4$ th segment of pedipalps longer than 3rd, coxae indistinct, solenidia on tibiae I-III and genua I-III, missing on genu IV, 3 rhagidial organs on tarsi I-II in continuous field, trichobothria absent . . . . . . . S. belli (Trouessart, 1902) - Average body length $>600 \mu \mathrm{m}$, 4th segment of pedipalps shorter than $3 \mathrm{rd}$, coxae well distinct, solenidia on all tibiae and genua I-IV, 3 oblique rhagidial organs on tarsus I in separated fields, 1 trichobothrium on leg IV . . . . . . . . . . 12

12. - Average body length $840 \mu \mathrm{m}$, middle lobe of the epirostrum with undulate margin, eyes large, 2 indistinct and irregular longitudinal grooves on hysterosoma, aggenital setae from 20 to 25 pairs, leg I longer than body, solenidia submedial, rhagidial organs missing on tarsus II, trichobothrium on tibia IV . . . . . . . . S. undulatus Strandtmann, 1964 - Middle lobe of the epirostrum round-shaped with regular margin, eyes indistinct, 2 prominent longitudinal grooves on hysterosoma, aggenital setae less than 20, leg I long as body, solenidia usually all basal, 3 oblique rhagidial organs in separated fields on tarsi I-II, trichobothrium on tarsus IV . . . . . . . . . . . . . 13

13. - Average body length $630 \mu \mathrm{m}, 8$ apical palps setae, 3 pairs of slit pores on hysterosoma, aggenital setae from 10 to 11 pairs, leg IV longer than body, solenidium on genu I dorso-basal or apical, 1-2 small apical rhagidiform organ(s) on tibia I, basal small simple setae on rhagidial organ of tarsus II ... . . . . S. villosus (Trouessart, 1902)

- Average body length $667 \mu \mathrm{m}, 7$ apical palps setae, slit pores on hysterosoma indistinct or absent, aggenital setae from 10 to 18 pairs, leg IV long as the body, solenidium on genu I always dorso-basal, 1 apical small rhagidiform organ on tibia and genu I, basal small setae missing on rhagidial organ of tarsus II ... S. reticulatus Strandtmann, 1970

\section{Discussion}

The two newly described species are placed in the genus Stereotydeus following the key of the free-living mites of Antarctica provided by Strandtmann [7] and in particular because of the presence of a trilobed epirostrum with epivertex at the base of the middle lobe, the genitalia placed in a distinct and nearly circular camerostome and covered by two valves and the dorsum with a more or less defined reticulated pattern [6]. 
It was possible to distinguish Stereotydeus ineffabilis sp. nov. from the other species belonging to the genus because of (i) the small size of the adults (ca. $100 \mu \mathrm{m}$ smaller if compared to, e.g., S. mollis; see Table A2); (ii) the fourth segment of the pedipalps being as long as the third (longer in the other Stereotydeus species from North Victoria Land (NVL), shorter in S. shoupi from South Victoria Land (SVL); Figure 1d, Table A2) and bearing seven setae (while e.g., S. belli and S. mollis have a cluster of eight setae; Figure 1d, Table A2); (iii) the equal length of the movable and fixed digits of the chelicerae (movable digit longer than the fixed one in S. belli, S. mollis and S. villosus [5]; see Figure 1c); (iv) the presence on the hysterosoma of two faintly visible longitudinal grooves (absent in e.g., $S$. mollis and S. shoupi; Figure 1a, Table A3) and of three dorso-lateral slit pores (absent in $S$. mollis and S. shoupi; Figures $1 \mathrm{a}$ and 5a, Table A4); (v) six pairs of genital setae (useful to distinguish $S$. shoupi, bearing seven pairs, from all other Stereotydeus species; Figures $1 \mathrm{~b}$ and 5b, Table A4); (vi) the number of aggenital setae (10 or 9 in S. ineffabilis sp. nov., while eight in some other species from Victoria Land, including S. delicatus, S. punctatus, S. mollis and S. shoupi; see Figures $1 \mathrm{~b}$ and $5 \mathrm{~b}$, Table A4); (vii) the ventral position of the anal opening (e.g., sub-terminal in S. delicatus and dorsal in S. punctatus; Figures $1 \mathrm{~b}$ and 5b, Table A5); (viii) the femora undivided (divided at the apical quarter in other species from continental Antarctica e.g., S. delicatus, S. punctatus, S. belli and S. meyeri; Figures 3, 4 and 5b, Table A5); (ix) the position of the solenidia on the tibiae and the genua (Figures 3 and 4, Table A6) and $(x)$ the asymmetry and different length of the tarsal rhagidial organs (Figures 2-4, Table A7).

For Stereotydeus nunatakis sp. nov., it was possible to distinguish it from the other species of the genus because of (i) the large size of the specimens (compared to S. mollis and S. shoupi recorded in SVL; Table A2); (ii) the fourth segment of the pedipalps being as long as the third (longer in the other Stereotydeus species from (NVL), shorter in S. shoupi from (SVL); Figures 6c and 8c, Table A2) and bearing seven setae (while eight are in, e.g., S. villosus and S. belli; Figures $6 \mathrm{c}$ and $8 \mathrm{c}$, Table A2); (iii) the absence on the hysterosoma of the longitudinal grooves (present in, e.g., S. belli and S. punctatus; Figures 6a and 8a, Table A3); (iv) the number of aggenital setae (10 with sometimes asymmetry at 9 or 11 in $S$. nunatakis sp. nov. while 8 in S. punctatus and 22 in S. belli; Figures $6 \mathrm{~b}$ and 8b, Table A4); (v) the sub-terminal, almost apical, position of the anal opening (e.g., dorsal in S. punctatus; Figures $6 \mathrm{~b}$ and $8 \mathrm{~b}$, Table A5); (vi) all femora divided (undivided in S. mollis, S. shoupi and $S$. ineffabilis sp. nov.; Figure 7, Table A5); (vii) the chaetotaxy of the legs (Figure 7, Tables 3, A6 and A7); (viii) the bulb-shaped and brush-like setae terminally on the tarsi (slender and plumose in S. punctatus and S. belli; Figures 7 and 8e,f); (ix) the mid-basal (ti. I, II, IV and g. I, II) and medial (ti., g. III) position of the solenidia (while in S. punctatus are all basal and in S. belli are apical (ti. I, II, III and g. I, II) and medial (ti. IV, g. III); Figure 7, Table A6).

\section{Conclusions}

Several decades after the first descriptions of Stereotydeus species from Antarctica, the current study describes two new species, S. ineffabilis sp. nov. and S. nunatakis sp. nov. With the exclusion of S. intermedius Trouessart 1907, the key presented here and the information in Appendix A provide robust and reliable tools for the rapid identification of Antarctic and sub-Antarctic representatives of Stereotydeus. Together with the new species described herein, future molecular genetic studies of three additional species from Victoria Land (S. belli, S. punctatus and S. delicatus) will shed light on the phylogenetic relationships within the genus and increase knowledge of the distribution of Stereotydeus species in continental Antarctica.

Author Contributions: Conceptualization, C.B. and A.C.; methodology, C.B.; validation, H.S., and P.P.F.; formal analysis, C.B.; investigation, C.B.; resources, A.C., P.P.F., F.N. and H.S.; data curation, C.B.; writing-original draft preparation, C.B.; writing-review and editing, C.B., A.C., F.N., P.C., H.S. and P.P.F.; visualization, C.B.; supervision, A.C. and H.S.; project administration, C.B. and A.C.; funding acquisition, A.C., F.N. and P.P.F. All authors have read and agreed to the published version of the manuscript. 
Funding: This study was funded by the Italian Program of Research in Antarctica (PNRA16_00234) to A.C. Partial support was also provided by the University of Siena. P.C. is supported by NERC core funding to the British Antarctic Survey's 'Biodiversity, Ecosystems and Adaptation' Team. The paper also contributes to the SCAR 'State of the Antarctic Ecosystem' (AntEco) international program.

Institutional Review Board Statement: Not applicable.

Informed Consent Statement: Not applicable.

Data Availability Statement: The list of the data presented in this study is available on https: //steu.shinyapps.io/MNA-generale/.

Acknowledgments: We would like to thank Alessandro Gradi and Massimo Migliorini for their technical assistance. We wish to thank also the two anonymous reviewers for their helpful comments.

Conflicts of Interest: The authors declare no conflict of interest. The funders had no role in the design of the study; in the collection, analyses, or interpretation of data; in the writing of the manuscript, or in the decision to publish the results.

\section{Appendix A}

To provide a clear overview of some morphological characteristics useful for the identification of all the Antarctic and sub-Antarctic Stereotydeus species known to date, different synoptic tables are provided below. All information regarding morphology has been extrapolated from the original descriptions of the authors, with additional personal observations by C.B. (cited in the tables). 


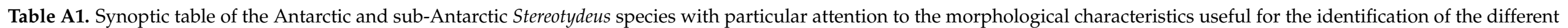
species. Abbreviations: Trouessart (Trou.); Womersley (Wom.); Strandtmann (Str.) and Pittard (Pitt.).

\begin{tabular}{|c|c|c|c|c|c|}
\hline Species & Lat (S) & Long & ACBRs/Area ${ }^{1}$ & References $^{2}$ & General Description \\
\hline $\begin{array}{l}\text { S. delicatus } \\
\text { Str., } 1967\end{array}$ & $66^{\circ}-72^{\circ} 23^{\prime}$ & $163^{\circ} \mathrm{E}-170^{\circ} 13^{\prime} \mathrm{E}$ & NVL & [7] & $\begin{array}{l}\text { Finely striated, sculptured and } \\
\text { reticulated }\end{array}$ \\
\hline S. punctatus Str., 1967 & $71^{\circ} 18^{\prime}-72^{\circ} 40^{\prime}$ & $169^{\circ} 25^{\prime} \mathrm{E}-170^{\circ} 13^{\prime} \mathrm{E}$ & NVL & [7] & $\begin{array}{l}\text { Heavily sculptured, podosoma } \\
\text { punctato-reticulate }\end{array}$ \\
\hline $\begin{array}{l}\text { S. belli } \\
\text { (Trou., 1902) } \\
\end{array}$ & $71^{\circ}-74^{\circ} 04^{\prime}$ & $165^{\circ} 18^{\prime} \mathrm{E}-172^{\circ} \mathrm{E}$ & NVL & {$[5,7]$} & $\begin{array}{l}\text { Lightly sclerotized, distinctive } \\
\text { sculpturing }\end{array}$ \\
\hline $\begin{array}{c}\text { S. mollis } \\
\text { Wom. and Str., } 1963\end{array}$ & $74^{\circ}-78^{\circ} 05^{\prime}$ & $161^{\circ} \mathrm{E}-168^{\circ} \mathrm{E}$ & $\begin{array}{c}\text { SVL; } \\
\text { Transantarctic Mountains }\end{array}$ & {$[2,5,7]$} & Soft body, almost no sculpturing \\
\hline $\begin{array}{l}\text { S. shoupi } \\
\text { Str., } 1967\end{array}$ & $79^{\circ} 52^{\prime}-84^{\circ} 73^{\prime}$ & $159^{\circ} 9^{\prime} \mathrm{E}-176^{\circ} 29^{\prime} \mathrm{E}$ & $\begin{array}{c}\text { SVL; } \\
\text { Transantarctic Mountains }\end{array}$ & [7] & $\begin{array}{l}\text { Soft body, poorly sclerotized almost } \\
\text { no sculpturing, similar to S. mollis }\end{array}$ \\
\hline $\begin{array}{l}\text { S. meyeri } \\
\text { Str., } 1967\end{array}$ & $67^{\circ} 30^{\prime}-?$ & $46^{\circ} \mathrm{E}-?$ & Enderby Land & [7] & $\begin{array}{l}\text { Delicate, distinct reticulate pattern on } \\
\text { dorsum and sides }\end{array}$ \\
\hline $\begin{array}{l}\text { S. villosus } \\
\text { (Trou., 1902) }\end{array}$ & $60^{\circ} 35^{\prime}-71^{\circ} 50^{\prime}$ & $68^{\circ} 30^{\prime} \mathrm{W}-45^{\circ} 30^{\prime} \mathrm{W}$ & $\begin{array}{l}\text { NW Antarctic Peninsula; South } \\
\text { Shetland Is.; } \\
\text { South Orkney Is. }\end{array}$ & {$[5,7]$} & $\begin{array}{l}\text { Well sclerotized, with ridges, furrows } \\
\text { and polygonal marks }\end{array}$ \\
\hline S. intermedius Trou., 1907 & $60^{\circ} 43^{\prime}-?$ & $44^{\circ} 31^{\prime} \mathrm{W}-?$ & South Orkney Is. & {$[15,16]$} & $\begin{array}{l}\text { Oval, without shoulders, general } \\
\text { aspect similar to S. villosus }\end{array}$ \\
\hline S. reticulatus Str., 1970 & $54^{\circ} 0^{\prime}-54^{\circ} 32^{\prime}$ & $36^{\circ} 0^{\prime} \mathrm{W}-38^{\circ} 3^{\prime} \mathrm{W}$ & South Georgia & [16] & $\begin{array}{l}\text { Heavily sclerotized, with } \\
\text { reticulations/pubescent polygons }\end{array}$ \\
\hline $\begin{array}{l}\text { S. longipes } \\
\text { Str., } 1970\end{array}$ & $54^{\circ} 0^{\prime}-54^{\circ} 32^{\prime}$ & $36^{\circ} 0^{\prime} \mathrm{W}-38^{\circ} 3^{\prime} \mathrm{W}$ & South Georgia & [16] & $\begin{array}{l}\text { Well sclerotized, dorsum uniformly } \\
\text { pitted, finely striated }\end{array}$ \\
\hline S. nudisetatus Str., 1964 & $53^{\circ} 32^{\prime}-?$ & $169^{\circ} 08^{\prime} \mathrm{E}-?$ & Campbell Is. & [6] & $\begin{array}{l}\text { Coarsely hirsute, pubescence in } \\
\text { vague polygons (dorsal) and regular } \\
\text { polygons (ventral), tuberculate } \\
\text { margins of the body }\end{array}$ \\
\hline $\begin{array}{l}\text { S. pulcher } \\
\text { Str., } 1964\end{array}$ & $53^{\circ} 32^{\prime}-?$ & $169^{\circ} 08^{\prime} \mathrm{E}-?$ & Campbell Is. & [6] & $\begin{array}{l}\text { Prominent polygonal reticulations, } \\
\text { sparsely and finely pubescent }\end{array}$ \\
\hline S. undulatus Str., 1964 & $53^{\circ} 32^{\prime}-?$ & $169^{\circ} 08^{\prime} \mathrm{E}-?$ & Campbell Is. & [6] & $\begin{array}{c}\text { Body elliptical, numerous setae } \\
\text { (ventral), fairly regular pubescent } \\
\text { polygons }\end{array}$ \\
\hline $\begin{array}{l}\text { S. ineffabilis } \\
\text { sp. nov. }\end{array}$ & $74^{\circ} 42^{\prime}-75^{\circ} 53^{\prime}$ & $162^{\circ} 35^{\prime} \mathrm{E}-164^{\circ} 06^{\prime} \mathrm{E}$ & $\begin{array}{l}\text { NVL; } \\
\text { SVL }\end{array}$ & this paper & $\begin{array}{c}\text { Soft body, barely visible sculpturing, } \\
\text { sclerotization almost absent }\end{array}$ \\
\hline $\begin{array}{l}\text { S. nunatakis } \\
\text { sp. nov. }\end{array}$ & $75^{\circ} 41^{\prime}-75^{\circ} 53^{\prime}$ & $162^{\circ} 35^{\prime} \mathrm{E}-162^{\circ} 52^{\prime} \mathrm{E}$ & SVL & this paper & $\begin{array}{l}\text { Soft body, well sclerotized, clearly } \\
\text { visible sculptured pattern }\end{array}$ \\
\hline
\end{tabular}

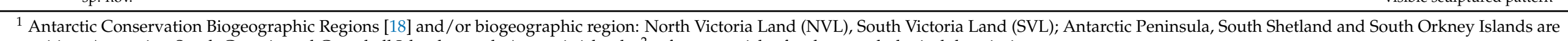
maritime Antarctica; South Georgia and Campbell Island are sub-Antarctic islands; ${ }^{2}$ reference articles for the morphological description. 


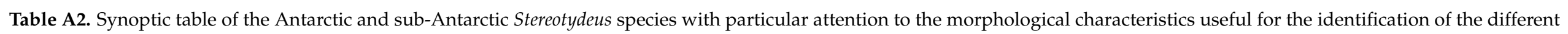
species. When a characteristic was not in the main text of the description, the reference drawings were used to extrapolate the data and mentioned in the table; on drawing (o.d.).

\begin{tabular}{|c|c|c|c|c|c|c|}
\hline \multirow{2}{*}{ Species } & \multirow{2}{*}{$\begin{array}{c}\text { Ref. } \\
\text { Drawings }\end{array}$} & \multirow{2}{*}{ Length ${ }^{4}(\mu \mathrm{m})$} & \multicolumn{2}{|c|}{ Gnathosoma } & \multicolumn{2}{|c|}{ Epirostrum (Trilobed) } \\
\hline & & & Pedipalps Segments 5 & N. Apical Palpal Setae & Middle Lobe & Lateral Lobes \\
\hline S. delicatus & [7], Figure 6 & 450 & 4 th $>3$ rd & $\begin{array}{l}7 \text { C.B. pers. obs. (not } \\
\text { visible o.d. Figure 6) }\end{array}$ & Prominent & Weakly developed \\
\hline S. punctatus & [7], Figure 4 & 400 & 4 th $>3$ rd & $\begin{array}{l}7 \text { C.B. pers. obs. (not clear } \\
\text { o.d. Figure } 4 \mathrm{~d} \text { ) }\end{array}$ & $\begin{array}{l}\text { Obtusely pointed, } \\
\text { obvious, pubescent }\end{array}$ & Punctate, angulate \\
\hline S. belli & [5], Figures 17-23 & 560 & 4 th $>3$ rd & 8 & Obtusely pointed & Obtusely pointed \\
\hline S. mollis & $\begin{array}{l}\text { [5], Figures } 4-8 ; \text { [2], Figures } \\
1 \text { and } 2\end{array}$ & 500 & 4 th $>3$ rd & 8 & Obtusely pointed & $\begin{array}{c}\text { Weakly, obscurely } \\
\text { developed }\end{array}$ \\
\hline S. shoupi & [7], Figure 3 & 450 & 4 th $<3$ rd & $\begin{array}{l}\text { missing data (not visible } \\
\text { o.d. Figure 3) }\end{array}$ & Mere suggestion & Mere suggestion \\
\hline S. meyeri & [7], Figure 5 & 400 & $\begin{array}{c}4 \text { th }=3 \text { rd } \\
\text { (o.d. Figure } 5 a, b)\end{array}$ & $\begin{array}{l}\text { missing data (not visible } \\
\text { o.d. Figure 5) }\end{array}$ & Evident & Well developed \\
\hline S. villosus & [5], Figures 9-16 & 630 & 4 th $<3$ rd & 8 & Prominent, smooth & Papillated \\
\hline S. intermedius & [15], no figure & 700 & $\begin{array}{l}\text { 4th long, } \\
\text { slender }\end{array}$ & missing data & Obtuse, large & Small \\
\hline S. reticulatus & [16], Figure 2 & 667 & 4 th $<3$ rd & 7 & Round/obtusely pointed & Angulate \\
\hline S. longipes & [16], Figure 5 & $\begin{array}{l}\text { ơ } 525 \\
\text { ○540; }\end{array}$ & 4 th $\geqq 3$ rd & $\begin{array}{l}8 ? \text { (not clear o.d. } \\
\text { Figure } 5 \mathrm{c} \text { ) }\end{array}$ & $\begin{array}{l}\text { Obtusely pointed, } \\
\text { smooth, pubescent }\end{array}$ & Small, pitted, rounded \\
\hline S. nudisetatus & [6], Figure 4 & 435 & 4 th $>3$ rd & 7 & $\begin{array}{l}\text { Large, triangular, long, } \\
\text { pubescent }\end{array}$ & $\begin{array}{l}\text { Large, triangular, } \\
\text { tuberculate }\end{array}$ \\
\hline S. pulcher & [6], Figure 5 & 500 & 4 th $<3$ rd & 7 & $\begin{array}{l}\text { Half-circle, broad, faintly } \\
\text { reticulated, pubescent }\end{array}$ & Deeply pocked \\
\hline S. undulatus & [6], Figures 2 and 3 & 840 & 4 th $<3$ rd & 7 & $\begin{array}{l}\text { Scalloped/undulate } \\
\text { margin, pubescent }\end{array}$ & Pubescents \\
\hline S. ineffabilis & Figures 1 and 5 & 414 & 4 th $=3 \mathrm{rd}$ & 7 & Evident & Weakly developed \\
\hline S. nunatakis & Figures 6 and 8 & 563 & $4 \mathrm{th}=3 \mathrm{rd}$ & 7 & $\begin{array}{l}\text { Evident, slightly } \\
\text { irregular margin }\end{array}$ & Narrow, well developed \\
\hline
\end{tabular}

${ }^{3}$ Figures from reference articles used for the descriptions; ${ }^{4}$ average body length ${ }^{5}>$ longer than; $<$ shorter than; $=$ as long as. 


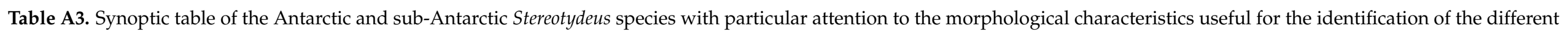
species. When a characteristic was not in the main text of the description, the reference drawings were used to extrapolate the data and mentioned in the table; on drawing (o.d.).

\begin{tabular}{|c|c|c|c|c|}
\hline \multirow{2}{*}{ Species } & \multirow{2}{*}{ Ref. Drawings ${ }^{3}$} & \multicolumn{3}{|c|}{ Dorsal Side } \\
\hline & & Propodosoma & Eyes & Hysterosoma \\
\hline S. delicatus & [7], Figure 6 & Faintly reticulate & Distinct, convex, smooth, finely striate & $\begin{array}{l}\text { Longitudinal grooves absent or very } \\
\text { weak }\end{array}$ \\
\hline S. punctatus & [7], Figure 4 & Faint horseshoe sometimes visible & $\begin{array}{l}\text { Large with coarse, oblique, punctate } \\
\text { striations }\end{array}$ & $\begin{array}{c}2 \text { shallow, parallel grooves just outside } \\
\text { dorsal setae }\end{array}$ \\
\hline S. belli & [5], Figures 17-23 & $\begin{array}{l}\text { Area between the eyes strongly } \\
\text { sclerotized }\end{array}$ & $\begin{array}{l}\text { Evident, well-formed, apparently } \\
\text { ciliated }\end{array}$ & $\begin{array}{l}2 \text { parallel grooves just outside dorsal } \\
\text { setae (o.d. Figure 18) }\end{array}$ \\
\hline S. mollis & [5], Figures 4-8; [2], Figures 1 and 2 & $\begin{array}{l}\text { Central area rectangular, weakly } \\
\text { sclerotized }\end{array}$ & $\begin{array}{l}\text { Well developed, strongly convex, lightly } \\
\text { striated }\end{array}$ & $\begin{array}{l}\text { Longitudinal grooves absent (o.d. } \\
\text { Figure 5), finely striated }\end{array}$ \\
\hline S. shoupi & [7], Figure 3 & - & Indistinct & $\begin{array}{l}\text { Longitudinal grooves absent (o.d. } \\
\text { Figure 3a) }\end{array}$ \\
\hline S. meyeri & [7], Figure 5 & $\begin{array}{l}\text { Punctate with faint crest forming an } \\
\text { incomplete horseshoe }\end{array}$ & Prominent, finely striated & $\begin{array}{c}2 \text { longitudinal grooves (vaguely visible } \\
\text { o.d. Figure 5a) }\end{array}$ \\
\hline S. villosus & [5], Figures 9-16 & - & Lens-like structure, not very clear & $\begin{array}{l}2 \text { prominent, longitudinal grooves just } \\
\text { outside dorsal setae (o.d. Figure 10) }\end{array}$ \\
\hline S. intermedius & [15], no figure & $\begin{array}{l}\text { Large triangular shield with round } \\
\text { angles; ridge divides shield into } 2 \text { oval } \\
\text { spaces }\end{array}$ & Missing data & $\begin{array}{l}\text { Longitudinal grooves absent, long, } \\
\text { rectangular as in S. villosus }\end{array}$ \\
\hline S. reticulatus & [16], Figure 2 & With single, rather indistinct arch & $\begin{array}{l}\text { Indistinct (o.d. } \\
\text { Figure 2a) }\end{array}$ & $\begin{array}{c}2 \text { prominent, longitudinal grooves just } \\
\text { outside dorsal setae }\end{array}$ \\
\hline S. longipes & [16], Figure 5 & No arched ridge & Prominent, striated & Longitudinal grooves absent \\
\hline S. nudisetatus & [6], Figure 4 & - & Distinct, finely striate (o.d. Figure 4a) & 2 faint longitudinal parallel grooves \\
\hline S. pulcher & [6], Figure 5 & - & Distinct, finely striate (o.d. Figure 5a) & $\begin{array}{l}2 \text { prominent, slightly divergent grooves } \\
\text { connect both with sejugal furrow and } \\
\text { together forming an } \mathrm{H}\end{array}$ \\
\hline S. undulatus & [6], Figures 2, 3 & Pubescent, with polygons & Large & $\begin{array}{l}2 \text { indistinct irregular longitudinal } \\
\text { grooves }\end{array}$ \\
\hline S. ineffabilis & Figures 1,5 & Barely visible reticulate pattern & Distinct, convex, finely striate & Longitudinal grooves vaguely visible \\
\hline S. nunatakis & Figures 6,8 & $\begin{array}{l}\text { Area between the eyes strongly } \\
\text { sclerotized }\end{array}$ & Distinct, convex, striated & Longitudinal grooves absent \\
\hline
\end{tabular}




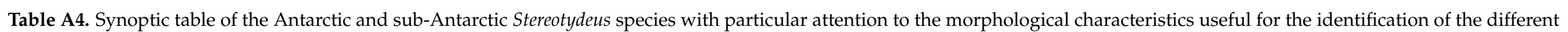

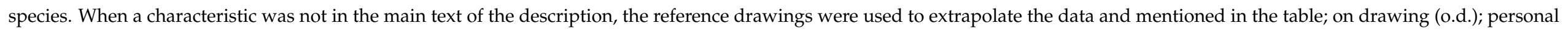
observations (pers. obs.).

\begin{tabular}{|c|c|c|c|c|c|}
\hline \multirow{2}{*}{ Species } & \multirow{2}{*}{$\begin{array}{c}\text { Ref. } \\
\text { Drawings }\end{array}$} & \multicolumn{2}{|c|}{ Dorsal Side } & \multicolumn{2}{|c|}{ Ventral Side } \\
\hline & & Dorso-Lateral Slit Pores & Sejugal Furrow & Genital Setae & Aggenital Setae \\
\hline S. delicatus & [7], Figure 6 & 3 pairs & $\begin{array}{l}\text { Weak (only dorsal o.d. Figure } \\
6 \mathrm{a} \text { ) }\end{array}$ & 6 pairs & 4 pairs \\
\hline S. punctatus & [7], Figure 4 & Indistinct (maybe lacking, C.B. pers. obs.) & Evident (only dorsal) & 6 pairs & 4 pairs \\
\hline S. belli & [5], Figures 17-23 & 3 pairs & Evident & 6 pairs & 11 pairs (o.d. Figure 17) \\
\hline S. mollis & $\begin{array}{c}\text { [5], Figures 4-8; } \\
\text { [2], Figures } 1 \text { and } 2\end{array}$ & Absent & $\begin{array}{l}\text { Absent (o.d. Figure 4; } \\
\text { Figure 2) or weak }\end{array}$ & 6 pairs & 4 pairs \\
\hline S. shoupi & [7], Figure 3 & Absent & Absent (o.d. Figure 3a) & 7 pairs & 4 pairs \\
\hline S. meyeri & [7], Figure 5 & 3 pairs (o.d. Figure 5a) & Absent (o.d. Figure 5b) & $\begin{array}{c}6 \text { pairs } \\
\text { (o.d. Figure } 5 b \text { ) }\end{array}$ & 4 pairs (o.d. Figure 5b) \\
\hline S. villosus & [5], Figures 9-16 & 3 pairs & Evident & 6 pairs & 10 to 11 pairs \\
\hline S. intermedius & [15], no figure & Missing data & Absent & Missing data & Missing data \\
\hline S. reticulatus & [16], Figure 2 & Indistinct (maybe lacking) & $\begin{array}{c}\text { Evident } \\
\text { (o.d. Figure 2b) }\end{array}$ & 6 pairs & 10 to 18 pairs \\
\hline S. nudisetatus & [6], Figure 4 & Missing data (not visible o.d. Figure 4a) & Shallow & 6 pairs & 5 pairs \\
\hline S. pulcher & [6], Figure 5 & Missing data (not visible o.d. Figure 5a) & Evident & $\begin{array}{c}6 \text { pairs } \\
\text { (o.d. Figure } 5 b \text { ) }\end{array}$ & 5 pairs \\
\hline S. undulatus & [6], Figures 2 and 3 & Missing data (not visible o.d. Figure 2a) & Evident & 6 pairs & 20 to 25 pairs \\
\hline S. ineffabilis & Figures 1 and 5 & 3 pairs & Evident & 6 pairs & $\begin{array}{l}5 \text { pairs (sometimes } \\
\text { asymmetric) }\end{array}$ \\
\hline S. nunatakis & Figures 6 and 8 & 3 pairs & $\begin{array}{c}\text { Evident } \\
\text { (only dorsal) }\end{array}$ & 6 pairs & $\begin{array}{l}5 \text { pairs (sometimes } \\
\text { asymmetric) }\end{array}$ \\
\hline
\end{tabular}




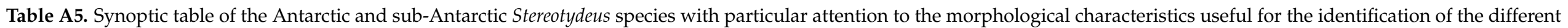

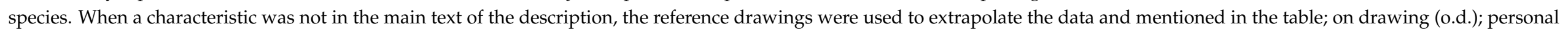
observations (pers. obs.).

\begin{tabular}{|c|c|c|c|c|c|}
\hline \multirow{2}{*}{ Species } & \multirow{2}{*}{$\begin{array}{c}\text { Ref. } \\
\text { Drawings }\end{array}$} & \multirow{2}{*}{ Anal Opening ${ }^{6}$} & \multicolumn{3}{|l|}{ Legs } \\
\hline & & & General Description & Coxae & Femora $^{7}$ \\
\hline S. delicatus & [7], Figure 6 & $\begin{array}{l}\text { Sub-terminal (on the margin, C.B. } \\
\text { pers. obs.) }\end{array}$ & $\begin{array}{l}\text { Slender, shorter than the body (o.d. } \\
\text { Figure 6) }\end{array}$ & Well distinct & At apical $1 / 4$ \\
\hline S. punctatus & [7], Figure 4 & Dorsal & $\begin{array}{l}\text { Finely pubescent, pedunculate, all } \\
\text { setae hirsute; I and } \\
\text { IV: longest but not as the body; II and } \\
\text { III: shorter }\end{array}$ & Indistinct & At apical $1 / 4$ \\
\hline S. belli & [5], Figures 17-23 & Ventral & $\begin{array}{c}\text { Slender; I and IV: } \\
\text { longest but not as the body }\end{array}$ & Indistinct (o.d. Figure 17) & At apical $1 / 4$ \\
\hline S. shoupi & [7], Figure 3 & $\begin{array}{l}\text { Ventral (almost sub-terminal o.d. } \\
\text { Figure 3a) }\end{array}$ & $\begin{array}{l}\text { Slender, shorter than the body, } \\
\text { abundant setae than other species of } \\
\text { the genus }\end{array}$ & Well distinct (o.d. Figure 3a) & Undivided \\
\hline S. meyeri & [7], Figure 5 & Sub-terminal & Slender, not long as the body & Well distinct (o.d. Figure 5b) & At apical $1 / 4$ \\
\hline S. villosus & [5], Figures 9-16 & Sub-terminal & $\begin{array}{l}\text { Slender; I long as the body, IV longer, } \\
\text { II and III shorter }\end{array}$ & Well distinct (o.d. Figure 9) & At apical $1 / 4$ \\
\hline S. intermedius & [15], no figure & Ventral (low) & I: longer than the body & Well distinct & I undivided \\
\hline S. reticulatus & [16], Figure 2 & Sub-terminal & $\begin{array}{c}\text { Slender, I and } \\
\text { IV as long as the body, II and III } \\
\text { shorter }\end{array}$ & Well distinct (o.d. Figure 2b) & At apical $1 / 4$ \\
\hline S. nudisetatus & [6], Figure 4 & Sub-terminal & $\begin{array}{l}\text { Shorter than the body, pubescent; } \\
\text { dorsal setae mainly nude, ventral } \\
\text { pectinate }\end{array}$ & Indistinct & At apical $1 / 4$ \\
\hline S. pulcher & [6], Figure 5 & Sub-terminal & $\begin{array}{l}\text { Shorter than the body, pubescent and } \\
\text { faintly reticulate; all segments } \\
\text { constricted basally }\end{array}$ & $\begin{array}{l}\text { Indistinct } \\
\text { (o.d. Figure 5b) }\end{array}$ & Undivided \\
\hline S. undulatus & [6], Figures 2 and 3 & Sub-terminal & $\begin{array}{l}\text { Slender; I longer than body, IV long } \\
\text { as the body, II and III shorter }\end{array}$ & Well distinct (o.d. Figure 2b) & At apical $1 / 4$ \\
\hline S. ineffabilis & Figures 1 and $3-5$ & Ventral & $\begin{array}{l}\text { Slender, shorter than the body; IV } \\
\text { longest, II shortest }\end{array}$ & Indistinct & Undivided \\
\hline S. nunatakis & Figures 6-8 & Sub-terminal & $\begin{array}{l}\text { Slender, shorter than the body; IV } \\
\text { longest, II shortest }\end{array}$ & Indistinct & At apical $1 / 4$ \\
\hline
\end{tabular}

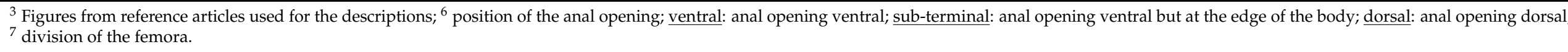




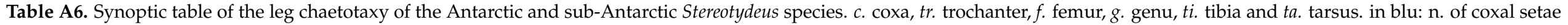
extrapolated from the drawings (following Pittard [2]); in green: n. of trochanter setae extrapolated from drawings; in red: possible mistakes in original articles.

\begin{tabular}{|c|c|c|c|c|c|c|c|c|c|}
\hline \multirow{2}{*}{ Species } & \multirow{2}{*}{ Ref. Drawings ${ }^{3}$} & \multirow{2}{*}{ Leg } & \multicolumn{6}{|c|}{ Setae } & \multirow{2}{*}{ Solenidia } \\
\hline & & & $c$. & tr. & $f$. & $g$. & $t i$. & $t a$. & \\
\hline \multirow{3}{*}{ S. delicatus } & \multirow{3}{*}{ [7], Figure 6} & $\mathrm{I}$ & 3 & 1 & \multirow{3}{*}{\multicolumn{4}{|c|}{$\begin{array}{l}\text { only general drawings available } \\
\text { (Figure } 6 \mathrm{a}, \mathrm{b})\end{array}$}} & sub-basal $(t i ., g)$. \\
\hline & & II & 1 & 1 & & & & & sub-basal (ti., g.) \\
\hline & & IV & 3 & $1(0)$ & & & & & sub-basal (ti.) \\
\hline \multirow{4}{*}{ S. punctatus } & \multirow{4}{*}{ [7], Figure 4} & I & 3 & 1 & 16 & 8 & 6 & 18 & dorso-basal $(t i ., g .)^{8}$ \\
\hline & & II & 1 & 1 & 11 & 5 & 6 & 15 & dorso-basal $(t i ., g .)^{8}$ \\
\hline & & III & 4 & 1 & 9 & 4 & 6 & 12 & dorso-basal $(t i ., g .)^{8}$ \\
\hline & & IV & 3 & 1 & 7 & 5 & 6 & 15 & dorso-basal (ti.) ${ }^{8}$ \\
\hline \multirow{4}{*}{ S. belli } & \multirow{4}{*}{ [5], Figure 17} & $\mathrm{I}$ & 3 & 1 & 24 & 13 & 8 & 21 & apical $(t i ., g)$. \\
\hline & & II & 1 & 1 & 18 & 7 & 8 & 17 & apical $(t i ., g)$. \\
\hline & & III & 4 & 1 & 14 & 5 & 8 & 16 & apical $(t i$.$) , medial (g.)$ \\
\hline & & IV & 3 & $1(2)$ & 10 & 6 & 9 & 15 & medial $(t i)$. \\
\hline \multirow{3}{*}{ S. mollis } & \multirow{3}{*}{$\begin{array}{l}\text { [5], Figure 4; } \\
\text { [2], Figure } 11\end{array}$} & $\mathrm{I}$ & 3 & 1 & 15 & 8 & 6 & 20 & mid-dorsal (ti., g.) \\
\hline & & II & 1 & 1 & 12 & 6 & $5^{9}$ & $14^{9}$ & mid-dorsal (ti., g.) \\
\hline & & III & 4 & 1 & 9 & 5 & 6 & $13^{9}$ & mid-dorsal (ti., g.) \\
\hline \multirow{4}{*}{ S. shoupi } & \multirow{4}{*}{ [7], Figure 3} & $\mathrm{I}$ & 3 & 1 & \multirow{4}{*}{\multicolumn{4}{|c|}{$\begin{array}{l}\text { only general drawings available } \\
\text { (Figure } 3 \mathrm{a}, \mathrm{b})\end{array}$}} & apical $(t i ., g)$. \\
\hline & & II & 1 & 1 & & & & & apical $(t i$.$) , subapical (g.)$ \\
\hline & & III & 4 & 1 & & & & & medial $(t i ., g)$. \\
\hline & & IV & 3 & 1 & & & & & medial $(t i)$. \\
\hline \multirow{4}{*}{ S. meyeri } & \multirow{4}{*}{ [7], Figure 5} & I & 3 & 1 & \multirow{4}{*}{\multicolumn{4}{|c|}{$\begin{array}{l}\text { only general drawings available } \\
\text { (Figure } 5 a, b)\end{array}$}} & dorso-basal (ti., g.) \\
\hline & & II & 1 & 1 & & & & & dorso-basal (ti., g.) \\
\hline & & III & 4 & 1 & & & & & dorso-basal (ti., g.) \\
\hline & & IV & 3 & 1 & & & & & dorso-basal (ti.) \\
\hline \multirow{4}{*}{ S. villosus } & \multirow{4}{*}{ [5], Figure 9} & I & 3 & 1 & \multirow{4}{*}{\multicolumn{4}{|c|}{$\begin{array}{l}\text { only general drawings available } \\
\text { (Figure 9) }\end{array}$}} & $\begin{array}{c}\text { dorsobasal (ti.), dorsobasal/apical } \\
(\text { g.) }\end{array}$ \\
\hline & & II & 1 & 1 & & & & & $\begin{array}{c}(g .) \\
\text { dorso-basal }(t i ., g .)\end{array}$ \\
\hline & & III & 4 & 1 & & & & & dorso-basal (ti., g.) \\
\hline & & IV & 3 & 1 & & & & & dorso-basal (ti., g.) \\
\hline
\end{tabular}


Table A6. Cont.

\begin{tabular}{|c|c|c|c|c|c|c|c|c|c|}
\hline \multirow{2}{*}{ Species } & \multirow{2}{*}{ Ref. Drawings ${ }^{3}$} & \multirow{2}{*}{ Leg } & \multicolumn{6}{|c|}{ Setae } & \multirow{2}{*}{ Solenidia } \\
\hline & & & $c$. & $t r$. & $f$. & $g$. & $t i$. & $t a$. & \\
\hline S. intermedius & [15] no figure & \multicolumn{8}{|c|}{ missing data } \\
\hline \multirow{3}{*}{ S. reticulatus } & \multirow{3}{*}{ [16], Figures 2-4 } & II & 1 & 1 & 16 & $7(8)$ & 8 & 16 & dorso-basal (ti., g.) \\
\hline & & III & 4 & 1 & $12(14)$ & $6(7)$ & 6 & $15(16)$ & dorso-basal (ti., g.) \\
\hline & & IV & 3 & 1 & 8 & 6 & 7 & 15 & dorso-basal $(t i ., g)$. \\
\hline \multirow{3}{*}{ S. longipes } & \multirow{3}{*}{ [16], Figures 5-7 } & I & 3 & 1 & 19 & 10 & 9 & 22 & dorso-basal $(t i ., g)$. \\
\hline & & III & 4 & 1 & 11 & 6 & 6 & 14 & dorso-basal (ti., g.) \\
\hline & & IV & 3 & 1 & 8 & 5 & 6 & $14(15)$ & dorso-basal (ti.) \\
\hline \multirow{4}{*}{ S. nudisetatus } & \multirow{4}{*}{ [6], Figure 4} & I & 3 & 1 & \multirow{4}{*}{\multicolumn{4}{|c|}{$\begin{array}{l}\text { only general drawings available } \\
\qquad(\text { Figure } 4 \mathrm{a}, \mathrm{b})\end{array}$}} & dorsal $(t i ., g)$. \\
\hline & & II & 1 & 1 & & & & & dorsal (ti., g.) \\
\hline & & III & 4 & 1 & & & & & dorsal $(t i ., g)$. \\
\hline & & IV & 3 & 1 & & & & & dorsal (ti.) \\
\hline \multirow{3}{*}{ S. pulcher } & \multirow{3}{*}{ [6], Figure 5} & I & 3 & 1 & \multirow{3}{*}{\multicolumn{4}{|c|}{$\begin{array}{l}\text { only general drawings available } \\
\qquad(\text { Figure } 5 \mathrm{a}, \mathrm{b})\end{array}$}} & dorso-basal (ti., g.) \\
\hline & & II & 1 & 1 & & & & & dorso-basal (ti., g.) \\
\hline & & IV & 3 & 1 & & & & & dorso-basal (ti.) \\
\hline \multirow{4}{*}{ S. undulatus } & \multirow{4}{*}{ [6], Figures 2 and 3} & $\mathrm{I}$ & 3 & 1 & \multirow{4}{*}{\multicolumn{4}{|c|}{$\begin{array}{l}\text { only general drawings available } \\
\qquad(\text { Figure } 2 \mathrm{a}, \mathrm{b})\end{array}$}} & sub-medial dorsal $(t i ., g)$. \\
\hline & & II & 1 & 1 & & & & & sub-medial dorsal $(t i ., g)$. \\
\hline & & III & 6 & 1 & & & & & sub-medial dorsal $(t i ., g)$. \\
\hline & & IV & 4 & 1 & & & & & sub-medial dorsal (ti., g.) \\
\hline \multirow{4}{*}{ S. ineffabilis } & \multirow{4}{*}{ Figures $1-5$} & $\mathrm{I}$ & 3 & 1 & $17(16)$ & 8 & 6 & $18(17)$ & mid-basal (ti.), (mid-)basal (g.) \\
\hline & & II & 1 & 1 & 15 & $6(7)$ & 6 & 13 & mid-basal (ti.), (mid-)basal (g.) \\
\hline & & III & 4 & 1 & $11(9)$ & 5 & 6 & $9(12)$ & mid-basal (ti.), (mid-)basal (g.) \\
\hline & & IV & 3 & 1 & 8 & 5 & 6 & 13 & mid-basal (ti.) \\
\hline \multirow{4}{*}{ S. nunatakis } & \multirow{4}{*}{ Figures 6-8 } & $\mathrm{I}$ & 3 & 1 & 17 & 11 & 6 & 21 & mid-basal $(t i ., g)$. \\
\hline & & II & 1 & 1 & 15 & 6 & 6 & 14 & mid-basal $(t i ., g)$. \\
\hline & & III & 4 & 1 & 10 & 5 & 6 & 12 & medial (ti.), medial/mid-basal (g.) \\
\hline & & IV & 3 & 1 & 8 & 5 & 6 & 15 & mid-basal $(t i)$. \\
\hline
\end{tabular}

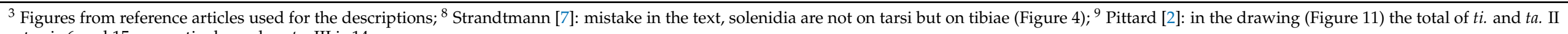
setae is 6 and 15, respectively, and on ta. III is 14 . 
Table A7. Synoptic table of the leg chaetotaxy of the Antarctic and sub-Antarctic Stereotydeus species. $n$. trichobotria, ti. tibia, ta. tarsus.

\begin{tabular}{|c|c|c|c|c|}
\hline Species & Ref. Drawings ${ }^{3}$ & Leg & $n$. & Solenidia \\
\hline \multirow[b]{3}{*}{ S. delicatus } & \multirow{3}{*}{ [7], Figure 6} & I & 0 & 2 tandem $(t a) ;$.1 apical small $(t i)$. \\
\hline & & II & 0 & 3 tandem in common field $(t a) ;$.1 apical small $(t i)$. \\
\hline & & III & 0 & - \\
\hline \multirow{4}{*}{ S. punctatus } & \multirow{4}{*}{ [7], Figure 4} & $\mathrm{I}$ & 0 & 2 oblique in confluent fields with stellate seta $(t a) ;$.1 apical small ( $t i)$. \\
\hline & & II & 0 & 3 in confluent fields $(t a) ;$.1 apical small $(t i)$. \\
\hline & & III & 0 & - \\
\hline & & IV & 0 & - \\
\hline \multirow{4}{*}{ S. belli } & \multirow{4}{*}{ [5], Figure 17} & I & 0 & 3 in continuous fields with basal small stellate seta $(t a) ;$.1 apical small ( $t i)$. \\
\hline & & II & 0 & 3 in continuous fields with basal small nude seta $(t a) ;$.1 apical small $(t i)$. \\
\hline & & III & 0 & - \\
\hline & & IV & 0 & 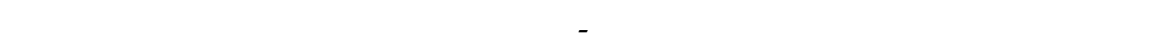 \\
\hline \multirow{4}{*}{ S. mollis } & \multirow{4}{*}{$\begin{array}{l}\text { [5], Figure 4; } \\
\text { [2], Figure } 11\end{array}$} & I & 0 & 3 longitudinal in confluent fields $(t a) ;$.1 apical small $(t i)$. \\
\hline & & II & 0 & 3 in confluent fields with basal small stellate seta $(t a) ;$.1 apical small ( $t i)$. \\
\hline & & III & 0 & - - \\
\hline & & IV & 1 ta. & - \\
\hline \multirow{3}{*}{ S. shoupi } & \multirow{3}{*}{ [7], Figure 3} & II & 0 & 3 tandem in confluent fields $(t a) ;$.1 apical small $(t i)$. \\
\hline & & III & 0 & 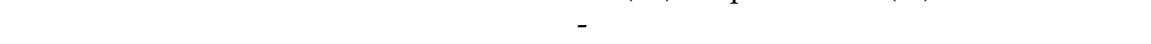 \\
\hline & & IV & $2(t a ., t i)$. & - \\
\hline \multirow{4}{*}{ S. meyeri } & \multirow{4}{*}{ [7], Figure 5} & I & 0 & 3 tandem in common field ( $t a) ;$.1 apical small $(t i)$. \\
\hline & & II & 0 & 3 tandem in common field $(t a) ;$.1 apical small $(t i)$. \\
\hline & & III & 0 & - \\
\hline & & IV & 0 & - \\
\hline \multirow{4}{*}{ S. villosus } & \multirow{4}{*}{ [5], Figure 9} & I & 0 & 3 oblique in separated fields with basal small stellate seta $(t a.) ; 1-2$ apical small (ti.) \\
\hline & & II & 0 & 3 oblique in separated fields with basal small simple seta (ta.); 1 apical small (ti.) \\
\hline & & III & 0 & 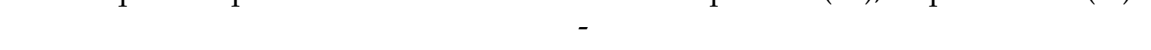 \\
\hline & & IV & 1 ta. & - \\
\hline S. intermedius & [15] no figure & & & missing data \\
\hline
\end{tabular}


Table A7. Cont.

\begin{tabular}{|c|c|c|c|c|}
\hline Species & Ref. Drawings ${ }^{3}$ & Leg & $n$. & Solenidia \\
\hline \multirow{4}{*}{ S. reticulatus } & \multirow{4}{*}{ [16], Figures 2-4 } & I & 0 & 3 oblique in separated fields with basal small stellate seta ( $t a) ;$.1 apical small (ti., g.) \\
\hline & & II & 0 & 3 oblique in separated fields $(t a) ;$.1 apical small $(t i ., g)$. \\
\hline & & III & 0 & - \\
\hline & & IV & $1 \mathrm{ta}$. & - \\
\hline \multirow{4}{*}{ S. longipes } & \multirow{4}{*}{ [16], Figures 5-7 } & I & 0 & 3 tandem in common field ( $t a) ;$.1 apical small ( $t i)$. \\
\hline & & II & 0 & 3 tandem in common field $(t a) ;$.1 apical small $(t i)$. \\
\hline & & III & 0 & - \\
\hline & & IV & 1 ta. & - \\
\hline \multirow{4}{*}{ S. nudisetatus } & \multirow{4}{*}{ [6], Figure 4} & $\mathrm{I}$ & 0 & 3 in line in separated fields $(t a) ;$.1 apical small $(t i)$. \\
\hline & & II & 0 & 3 in line, two in common field and one separated (ta.); 1 apical small ( $t i)$. \\
\hline & & III & 0 & 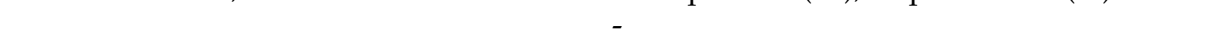 \\
\hline & & IV & $2(t a ., t i)$. & - \\
\hline \multirow{4}{*}{ S. pulcher } & \multirow{4}{*}{ [6], Figure 5} & I & 0 & 3 in separated fields: two apical parallel, basal oblique with small stellate seta $(t a)$. \\
\hline & & II & 0 & 3 in separated fields: two apical parallel, basal oblique with small nude seta $(t a)$. \\
\hline & & III & 0 & 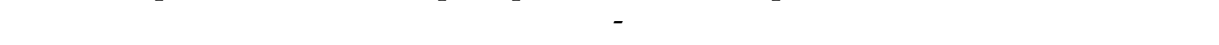 \\
\hline & & IV & 0 & - \\
\hline \multirow{3}{*}{ S. undulatus } & \multirow{3}{*}{ [6], Figures 2 and 3} & II & 0 & - \\
\hline & & III & 0 & - \\
\hline & & IV & $1 \mathrm{ti}$ & \\
\hline \multirow{4}{*}{ S. ineffabilis } & \multirow{4}{*}{ Figures 2-5 } & I & 0 & 3 unevenly set in $2-3$ separated fields with basal small nude seta $(t a) ;$.1 apical small ( $t i)$. \\
\hline & & II & 0 & 3 unevenly set in $2-3$ separated fields with basal small nude seta $(t a) ;$.1 apical small ( $t i)$. \\
\hline & & III & 0 & 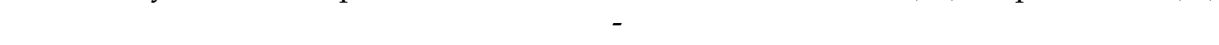 \\
\hline & & IV & $1 \mathrm{ta}$. & - \\
\hline \multirow{4}{*}{ S. nunatakis } & \multirow{4}{*}{ Figures 7 and 8} & I & 0 & 3 in line in common field with small nude seta $(t a) ;$.1 apical small $(t i)$. \\
\hline & & II & 0 & 3 in line in common field with small nude seta ( $t a) ;$.1 apical small (ti.) \\
\hline & & III & $1 \mathrm{ti}$ & - \\
\hline & & IV & $1 \mathrm{ta}$. & - \\
\hline
\end{tabular}

${ }^{3}$ Figures from reference articles used for the descriptions. 


\section{References}

1. Gressitt, J.L.; Shoup, J. Ecological Notes on Free-Living Mites in North Victoria Land. In Antarctic Research Series; Gressitt, J.L., Ed.; American Geophysical Union: Washington, DC, USA, 1967; pp. 307-320. ISBN 978-1-118-66869-6.

2. Pittard, D.A. A Comparative Study of the Life Stages of the Mite, Stereotydeus mollis W. \& S. (Acarina). Pac. Insects Monogr. 1971, 25, 1-14.

3. Pugh, P.J.A. A Synonymic Catalogue of the Acari from Antarctica, the Sub-Antarctic Islands and the Southern Ocean. J. Nat. Hist. 1993, 27, 323-421. [CrossRef]

4. Marshall, D.J.; Pugh, P.J.A. Origin of the Inland Acari of Continental Antarctica, with Particular Reference to Dronning Maud Land. Zool. J. Linn. Soc-Lond. 1996, 118, 101-118. [CrossRef]

5. Womersley, H.; Strandtmann, R.W. On Some Free Living Prostigmatic Mites of Antarctica. Pac. Insects 1963, 5, 22.

6. Strandtmann, R.W. Insects of Campbell Island. Prostigmata: Eupodidae, Penthalodidae, Rhagididae, Nanorchestidae, Tydeidae, Ereynetidae. Pac. Insects Monogr. 1964, 7, 148-165.

7. Strandtmann, R.W. Terrestrial Prostigmata (trombidiform mites). In Antarctic Research Series; Gressitt, J.L., Ed.; American Geophysical Union: Washington, DC, USA, 1967; pp. 51-80. ISBN 978-1-118-66869-6.

8. Sinclair, B.J.; Sjursen, H. Terrestrial Invertebrate Abundance across a Habitat Transect in Keble Valley, Ross Island, Antarctica. Pedobiologia 2001, 45, 134-145. [CrossRef]

9. Sjursen, H.; Sinclair, B.J. On the Cold Hardiness of Stereotydeus mollis (Acari: Prostigmata) from Ross Island, Antarctica. Pedobiologia 2002, 46, 188-195. [CrossRef]

10. Caruso, T.; Bargagli, R. Assessing Abundance and Diversity Patterns of Soil Microarthropod Assemblages in Northern Victoria Land (Antarctica). Polar Biol. 2007, 30, 895-902. [CrossRef]

11. Stevens, M.I.; Hogg, I.D. Contrasting Levels of Mitochondrial DNA Variability between Mites (Penthalodidae) and Springtails (Hypogastruridae) from the Trans-Antarctic Mountains Suggest Long-Term Effects of Glaciation and Life History on Substitution Rates, and Speciation Processes. Soil Biol. Biochem. 2006, 38, 3171-3180. [CrossRef]

12. McGaughran, A.; Hogg, I.D.; Stevens, M.I. Patterns of Population Genetic Structure for Springtails and Mites in Southern Victoria Land, Antarctica. Mol. Phylogenet. Evol. 2008, 46, 606-618. [CrossRef] [PubMed]

13. Demetras, N.J.; Hogg, I.D.; Banks, J.C.; Adams, B.J. Latitudinal Distribution and Mitochondrial DNA (COI) Variability of Stereotydeus spp. (Acari: Prostigmata) in Victoria Land and the Central Transantarctic Mountains. Antarct. Sci. 2010, 22, 749-756. [CrossRef]

14. Pittard, D.A.; Roberts, L.A.; Strandtmann, R.W. Morphological Variation in Three Populations of the Antarctic Mite, Stereotydeus mollis W. and S. (Arthropoda: Acarina). Acarologia 1971, 13, 88-97.

15. Trouessart, E.L. Acari of the Scotch Antarctic Expedition. Appendix in The Acari of the Swedish south polar expedition. In Wissenchaftliche Ergebnisse der Schwedischen Südpolar-Expedition 1901-1903; Lithographisches institut des Generalstabs: Stockholm, Sweden, 1907; Volume 5.

16. Strandtmann, R.W. Acarina: Eupodiform Prostigmata of South Georgia. Pac. Insects Monogr. 1970, 23, 89-106.

17. Fredes, N.A. First Record of Stereotydeus areolatus Womersley 1935 (Trombidiformes: Penthalodidae) from Soils in Argentina, with Comments of Stereotydeus Species. Acta Arachnol. 2015, 64, 33-37. [CrossRef]

18. Terauds, A.; Lee, J.R. Antarctic Biogeography Revisited: Updating the Antarctic Conservation Biogeographic Regions. Divers. Distrib. 2016, 22, 836-840. [CrossRef] 